\title{
ESSAY
}

\section{A THIRD WAY FOR THE VOTING RIGHTS ACT: SECTION 5 AND THE OPT-IN APPROACH}

\author{
Heather K. Gerken*
}

\begin{abstract}
One of the most powerful and intrusive civil rights provisions ever passed - section 5 of the Voting Rights Act-is scheduled to sunset in 2007. Congressional hearings on its fate have already begun. Section 5 requires select localities - mostly states in the Deep South-to ask the federal government's permission before making any change in the way they run elections. Despite its successes, section 5 remains extremely controversial. Even experts on the Act are deeply divided as to what Congress should do.

Our choice is not, as the current debate suggests, between maintaining the Act's decades-old regulatory structure and allowing section 5 to expire. There is a more dynamic approach, a middle ground that avoids the problems identified by the Act's critics while maintaining a robust safety net for minority voters. This Essay sets out to describe what such a third approach would look like. It proposes an "opt-in" system that would privilege local control and community involvement in voting rights enforcement. Such an approach would provide the right types of incentives for those involved in policing racial politics and deploy civil rights enforcement resources more effectively than the current system. More intriguingly, an opt-in approach would create a new set of institutional incentives for political elites to pay attention to the needs and concerns of those most affected by their decisions. An opt-in system offers a concrete strategy for tying the fate of political elites to minority voters and integrating debates about electoral structures into everyday politics. By reducing top-down regulation of election law, it may generate bottom-up support for voting rights enforcement.
\end{abstract}

* Professor of Law, Harvard Law School; Visiting Professor of Law, Yale Law School. For helpful conversation and comments, I would like to thank Ian Ayres, Guy Charles, Drew Days, Jack Goldsmith, Lani Guinier, Sam Hirsch, Sam Issacharoff, Michael Kang, Morgan Kousser, Daryl Levinson, Spencer Overton, Richard Pildes, Lisa Rodriguez-Taseff, David Simon, Bill Stuntz, two anonymous reviewers of the draft, and the participants in "The Coming Fire: Conference on the 2007 Renewal of the Voting Rights Act," sponsored by the Russell Sage Foundation. The portions of this Essay describing how section 5 is currently administered are based in part on interviews conducted with current and former officials from the Voting Section of the U.S. Department of Justice's (DOJ) Civil Rights Division, including: David Becker, a trial attorney of seven years; Michael Pitts, a trial attorney of four years and an analyst for two-and-a-half years; Anonymous I, an attorney with experience in the Voting Section; Anonymous II, a senior DOJ official who has worked in the Voting Section; and Anonymous III, a senior DOJ official familiar with the section 5 process. My thanks to all of them. Excellent research assistance was provided by Bryan Choi, Anton Metlitsky, Warren Postman, Amanda Teo, and Andrew Werbrock. Finally, I am indebted to the Russell Sage Foundation for its support in writing this Essay. 


\section{INTRODUCTION}

Section 5 of the Voting Rights Act (VRA, Act), the most powerful weapon in the civil rights arsenal, is scheduled to sunset in 2007. Congress has already begun debating the fate of what may be the most creative and burdensome strategy for protecting racial minorities ever enacted, while supporters and opponents of the Act are gearing up for a fight.

Even experts on the Act are deeply divided as to whether Congress should renew section 5. After a long period of relative unanimity, the academics who study the Act and the lawyers who enforce it are at an impasse, and they are split for reasons that have little to do with whose ox is gored. What divides them is a single question: Do racial minorities finally wield enough power in the political process to protect themselves? Supporters of renewal say our politics is still infected with racism and insist that we keep the VRA in its current form. Critics of the Act argue we have reached the world of "normal politics," where black and Latino legislators can hold their own in the bargaining process. They thus decry the command-and-control approach that has been used for decades to regulate racial politics. Some even argue that Congress should simply let the relevant sections of the Act expire.

Rather than trying to resolve the intractable debate over whether we face entrenched racial divisions or normal politics, Congress should adopt a regulatory strategy that can work in the territory between these two extremes. Our choice is not, as everyone seems to think, between maintaining the Act's decades-old regulatory structure and seeking a fullscale withdrawal. There is a more dynamic approach, a middle ground that avoids the problems identified by the Act's critics while maintaining a robust safety net for minority voters. There is, in short, a third way for the Voting Rights Act.

This Essay sets out to describe what a third-way approach would look like. Drawing upon a range of administrative law and constitutional scholarship, it proposes an "opt-in" approach that would privilege local control and community involvement in voting rights enforcement. This approach would give community members a chance to bargain with localities over voting rights enforcement while providing them with meaningful protection should bargaining fail: a chance to "opt in" and invoke the remedies traditionally afforded by the Voting Rights Act. Concomitantly, if local community members did not affirmatively opt in to VRA coverage, the change would not be second-guessed by the Department of Justice (DOJ) or the courts.

Thus, under an opt-in approach, community and legislative leaders would have a chance to negotiate the best deal possible for racial minorities. They would do so, however, with a bargaining chip in their pockets-a chance to demand that the Act's traditional constraints apply should bargaining break down. Political deals struck by racial minorities would be enforced, but the VRA would hang like the sword of Damocles 
over every negotiation. The key difference from the current regime is that the courts and the DOJ would assess whether the negotiating process was fair, not whether its end product was the "right" one for racial minorities. The fate of any challenge under the VRA would thus turn on the fairness of the process that produced the change, not on its substantive merits.

An opt-in approach would provide the right types of incentives for those involved in policing racial politics and deploy civil rights enforcement resources more effectively than the current system. This strategy might even help address some of the constitutional concerns associated with section 5 renewal.

More intriguingly, an opt-in approach would create a new set of institutional incentives for political elites-who all but unilaterally control how elections are run-to pay attention to the needs and concerns of those most affected by their decisions. An opt-in approach thus holds the potential-admittedly an elusive one-to transform our politics, as it offers a concrete strategy for tying the fate of political elites to minority voters and integrating debates about electoral structures into everyday politics. By reducing top-down regulation of election law, it may generate bottom-up support for voting rights enforcement.

Part I of this Essay describes the question that divides critics and supporters of the Act-whether we have reached a stage where racial minorities are powerful enough to protect themselves-and argues that it is all but unanswerable. Part II suggests that the better approach is not to try to resolve this debate, but to develop a flexible regulatory approach that works in a transitional world between entrenched racism and normal politics. It then describes what the opt-in approach would look like in practice, explaining why we ought to prefer such a strategy over either of the proposed alternatives: renewal of the Act in its current form or expiration of section 5's protections. Although an exhaustive analysis of the costs and benefits of this approach is beyond the scope of this Essay, Part II also addresses the primary counterarguments to the proposal. Part III moves from the concrete to the theoretical by placing this proposal in a broader intellectual context. It argues that the opt-in strategy offers an opportunity to exploit the lessons administrative law holds for election law scholars while showing how one might synthesize two distinct strains of election law scholarship: academic work emphasizing participatory values and scholarship premised on an elite-centered, competitive vision of electoral politics.

\section{The Question: Can Racial Minorities Now Protect Themselves?}

Section 5 of the Voting Rights Act is one of the most creative and burdensome laws protecting racial minorities. It requires select localities 
(covered jurisdictions $\left.^{1}\right)$ - mostly states in the Deep South-to ask the federal government's permission before making any change, no matter how small, in the way they run elections. ${ }^{2}$ This "preclearance" requirement has achieved spectacular results. It solved the central problem in voting rights enforcement during the civil rights era: keeping up with the increasingly creative strategies recalcitrant state and local governments used to disenfranchise black voters. Prior to passage of the VRA, discrimination by states and localities was difficult to police. The moment a court deemed one exclusionary practice illegal, local officials would switch to another. Literacy tests, poll taxes, citizenship tests, at-large districting schemes-all were used seriatim to prevent blacks from voting. The preclearance requirement shifted the burden of inertia, allowing the Department of Justice to get one step ahead of local officials by forbidding them to make any changes without its approval.

Despite its successes, section 5 remains extremely controversial. Covered jurisdictions must "preclear" thousands of changes with the Department of Justice every year. ${ }^{3}$ Many resent the fact that, some forty years after the VRA was passed, most Southern states remain under the watchful eye of the Department of Justice, even though the bulk of the flareups in recent elections have occurred in jurisdictions that are not covered by section 5 , like Ohio and the densely populated areas of Florida. ${ }^{4}$

1. A state or locality is deemed a covered jurisdiction using a formula designed to target the most egregious discriminators under section 4 of the Voting Rights Act. 42 U.S.C. $\$ 1973 b(b)(2000)$.

2. 42 U.S.C. $\$ 1973$ c. For general overviews of section 5 and the preclearance process, see Katharine Inglis Butler, Redistricting in a Post-Shaw Era: A Small Treatise Accompanied by Districting Guidelines for Legislators, Litigants, and Courts, 36 U. Rich. L. Rev. 137, 170-95 (2002); Drew S. Days III, Section 5 and the Role of the Justice Department, in Controversies in Minority Voting 52, 53-57 (Bernard Grofman \& Chandler Davidson eds., 1992); Hiroshi Motomura, Preclearance Under Section Five of the Voting Rights Act, 61 N.C. L. Rev. 189 (1983); Michael J. Pitts, Section 5 of the Voting Rights Act: A Once and Future Remedy?, 81 Denv. U. L. Rev. 225, 228-37 (2003) [hereinafter Pitts, Remedy]; Mark A. Posner, Post-1990 Redistricting and the Preclearance Requirements of Section 5 of the Voting Rights Act, in Race and Redistricting in the 1990s, at 80, 83-110 (Bernard Grofman ed., 1998) [hereinafter Posner, Post-1990]; Meghann E. Donahue, Note, "The Reports of My Death Are Greatly Exaggerated": Administering Section 5 of the Voting Rights Act After Georgia v. Ashcroft, 104 Colum. L. Rev. 1651, 1653-62 (2004).

3. According to the DOJ website, it received the following number of preclearance requests from 2000-2004: 2004 (5,153); 2003 (4,740); 2002 (5,696); 2001 (3,969); 2000 $(4,420)$. The numbers are derived from a manual count from data in Civil Rights Div., U.S. Dep't of Justice, Archive of Notices of Preclearance Activity Under the Voting Rights Act of 1965, as Amended, at http://www.usdoj.gov/crt/voting/notices/votarch.html (last revised Jan. 9, 2006) (on file with the Columbia Law Review); Civil Rights Div., U.S. Dep't of Justice, Notices of Section 5 Activity Under the Voting Rights Act of 1965, as Amended, at http:// www.usdoj.gov/crt/voting/notices/noticepg.html (last revised Jan. 30, 2006) (on file with the Columbia Law Review) [hereinafter DOJ Notices of Section 5 Activity].

4. Although five counties in Florida (Collier, Hardee, Hendry, Hillsborough, and Monroe) are covered by section 5, see Civil Rights Div., U.S. Dep't of Justice, Section 5 Covered Jurisdictions, at http://www.usdoj.gov/crt/voting/sec_5/covered.htm (last visited 
Section 5 also has an odd political valence. Some parts of the Democratic Party, traditionally the party most supportive of civil rights, fear that section 5 has led to the creation of too many "majority-minority districts"-those where racial minorities can constitute a majority on election day. Given that African Americans and certain Hispanics vote heavily Democratic, these Democrats have long worried that majority-minority districts pack Democratic voters and let Republicans win more seats than they should. Some even blame the Democratic Party's loss of the House on the aggressive creation of majority-minority districts during the 1990s, a trend spurred in part by section $5 .{ }^{5}$ Republicans, meanwhile, often oppose race-based government decisionmaking. They may have, however, benefited from the use of race in section 5 redistricting, and the Department of Justice under the first President Bush was widely known for its aggressive enforcement of section 5's districting mandates. ${ }^{6}$

It is easy to see why partisans on both sides of the issue might disagree on whether and how to extend section 5's lifespan. What is interesting is that the longstanding consensus among those most knowledgeable

Nov. 16, 2005) (on file with the Columbia Law Review), these were not the counties where the most serious problems of 2000 and 2004 occurred.

5. This issue has been a source of heated debate among political scientists as well. See, e.g., Carol M. Swain, Black Faces, Black Interests 200-05 (1993) (discussing need to look beyond majority-minority districts as way to ensure and increase political representation of blacks); Charles S. Bullock, III \& Richard E. Dunn, The Demise of Racial Redistricting and the Future of Black Representation, 48 Emory L.J. 1209, 1214-15 (1999) (arguing that previous premises about racial voting cohesion and crossover have become outdated, requiring reevaluation of need for majority-minority districts); Charles Cameron et al., Do Majority-Minority Districts Maximize Substantive Black Representation in Congress?, 90 Am. Pol. Sci. Rev. 794, 794-95 (1996) (arguing that drawing districts in order to ensure greater number of minority representatives has effect of diluting broader minority supportive representation, reducing successful passage of legislation that furthers interests of minorities); Bernard Grofman et al., Drawing Effective Minority Districts: A Conceptual Framework and Some Empirical Evidence, 79 N.C. L. Rev. 1383, 1392-94 (2001) (arguing that role of primary elections, not just minority electoral participation, should be factored into calculations determining percentage of minorities needed to create "effective minority district"); Lisa Handley et al., Electing Minority-Preferred Candidates to Legislative Office: The Relationship Between Minority Percentages in Districts and the Election of Minority-Preferred Candidates, in Race and Redistricting in the 1990s, supra note 2, at 13, 37 (arguing that statistical evidence demonstrates "significant growth in the number of African-American and Hispanic elected officials" that was "due to the increase in the number of majority minority districts created"); David Lublin, Racial Redistricting and African-American Representation: A Critique of "Do Majority-Minority Districts Maximize Substantive Black Representation in Congress?", 93 Am. Pol. Sci. Rev. 183, 186 (1999) (arguing that racial redistricting is "vital" to election of African Americans to Congress).

6. Ted Shaw, the top lawyer at the NAACP Legal Defense and Educational Fund, summed up the conventional wisdom this way: Despite the DOJ's failure to push civil rights enforcement in most areas, it is well known that the Voting Section under the Bush I administration "enforce[d] the Voting Rights Act with a vengeance." Theodore M. Shaw, Keynote Address at the Temple Political and Civil Rights Law Review Symposium: Constructive Disenfranchisement: The Problems of Access \& Ambiguity Facing the American Voter (Oct. 27, 2001), 11 Temp. Pol. \& Civ. Rts. L. Rev. 299, 306 (2002). 
about the Act-the lawyers who enforce it and the academics who study it-seems to have broken down as well.

The question that divides the experts is this: Given the impressive gains racial minorities have made during the last forty years, do they now wield enough power in the political process to protect themselves? To understand why the views of the experts differ, consider a concrete example: Georgia's redistricting process after the 2000 census. In 2001, a coalition of white and black Democrats passed a redistricting plan through the state legislature that reduced the number of districts where the population was more than sixty percent minority to increase the chances that Democrats would retain control of the state legislature. ${ }^{7}$ The political calculus behind that judgment was simple: Spreading out black voters increased the likelihood that the party of choice for most African Americans-the Democratic Party-would retain legislative control. Concentrating black voters in majority-minority districts was, in the view of supporters of the plan, simply a recipe for ensuring that candidates representing minority communities would lose legislative control, committee chairs, and the many other benefits associated with being part of the majority party. ${ }^{8}$

Although the plan was supported by virtually all of the black state legislators as well as civil rights icon John Lewis, ${ }^{9}$ the Department of Justice opposed the plan for the Georgia Senate, and the district court from which Georgia sought preclearance rejected the plan on the ground that it unduly reduced black voting strength. ${ }^{10}$ The lower court's ruling was unsurprising. Up until then, the Supreme Court and lower courts had almost universally favored majority-minority districts as the preferred solution to the problem of racially polarized voting.

The case, Georgia v. Ashcroft, eventually worked its way to the Supreme Court, which rejected the DOJ's position, vacated the lower court's decision, and remanded for a preclearance assessment under the new standard articulated by the Court. ${ }^{11}$ In doing so, the Court deferred to the judgment of state legislators that blacks were better served by a plan that increased Democratic strength even though it reduced the number of districts where they could control electoral outcomes. ${ }^{12}$

7. Georgia v. Ashcroft, 539 U.S. 461, 469-70 (2003).

8. Cf. id. at 483-84 (discussing assessment of minority group political participation in terms of "[m]aintaining or increasing legislative positions of power for minority voters' representatives").

9. Id. at 471, 489-90.

10. See Georgia v. Ashcroft, 195 F. Supp. 2d 25, 31 (D.D.C. 2002). Section 5 allows a covered jurisdiction to choose between seeking preclearance from the Department of Justice or from a three-judge district court in the District of Columbia Circuit. 42 U.S.C. $\S 1973 \mathrm{c}$ (2000).

11. See 539 U.S. at 475, 487-88, 491.

12. See id. at 483-86. 
Some experts argue that the Court got it right in Georgia. ${ }^{13}$ Why, they ask, should a court or the Department of Justice impose a particular vision of equality on minority voters in a case like Ashcroft, where black legislators not only favored the challenged plan but had enough votes to block it had they chosen to do so? ${ }^{14}$ In a world of intense partisan competition, ${ }^{15}$ where black and Latino legislators play important roles in the dealmaking process, ${ }^{16}$ academics like Richard Pildes and Samuel Issacharoff ask whether we ought to allow any institution-let alone a potentially partisan one ${ }^{17}$ — to second-guess the judgments of duly elected legislators representing minority communities. Perhaps, they suggest, we should recognize that even in the Deep South, we have achieved what Pildes calls the "normal, pluralist interest group politics to which the VRA aspired." 18 Rather than impose a particular view about what kind of representation is "fair" on blacks or Latinos, we can simply let members of those groups do what any other political minority does in a healthy democracy: negotiate the best deal possible. The "command-and-control" 19 approach to civil rights enforcement, these academics argue, is a relic of the past. Some go a good deal farther than Pildes and Issacharoff, arguing that section 5 no longer serves a useful role in regulating racial politics and urging Congress to let it expire. ${ }^{20}$

13. See, e.g., Samuel Issacharoff, Is Section 5 of the Voting Rights Act a Victim of Its Own Success?, 104 Colum. L. Rev. 1710, 1716-20 (2004) [hereinafter Issacharoff, Own Success]; Richard H. Pildes, Foreword: The Constitutionalization of Democratic Politics, 118 Harv. L. Rev. 28, 88-99 (2004) [hereinafter Pildes, Constitutionalization].

14. Ashcroft, 539 U.S. at 471 (noting that votes of ten of eleven black senators and thirty-three of thirty-four black representatives were necessary to pass districting plan).

15. Issacharoff and Pildes both place great emphasis on the role robust political competition may play in protecting the interests of minority voters. See Issacharoff, Own Success, supra note 13, at 1731 (noting that administrative complexity "together with the strengthened world of partisan competition has called into question the continued utility of administrative preclearance"); Samuel Issacharoff \& Richard H. Pildes, Politics as Markets: Partisan Lockups of the Democratic Process, 50 Stan. L. Rev. 643, 646 (1998) ("Only through an appropriately competitive partisan environment can one of the central goals of democratic politics be realized: that the policy outcomes of the political process be responsive to the interests and views of citizens."); Pildes, Constitutionalization, supra note 13, at 97 ("[C] ompetition itself creates the incentives and provides the checks that most effectively realize representational equality.”).

16. See Samuel Issacharoff \& Pamela S. Karlan, Groups, Politics, and the Equal Protection Clause, 58 U. Miami L. Rev. 35, 44-45 (2003) [hereinafter Issacharoff \& Karlan, Groups] ("By the post-1990 round of redistricting, blacks and Hispanics had progressed from being literally locked out of the room in which political deals were cut to being key members of state legislative redistricting committees." (footnote omitted)).

17. See Issacharoff, Own Success, supra note 13, at 1714 (noting "charges of partisan misuse of the preclearance provisions of the VRA" and speculating as to whether such partisanship casts doubt on continued effectiveness of section 5).

18. Pildes, Constitutionalization, supra note 13 , at 97.

19. Id. at 95 .

20. Neither Pildes nor Issacharoff has firmly committed to the view that section 5 ought to expire in 2007; thus far, their written work has only raised questions about the wisdom of renewal of section 5 in its current form. Moreover, their work has largely 
Other experts take a quite different view of what happened in Georgia. Even if one thought that black legislators struck a good deal during the districting process-itself a hotly contested question-they did so only because they were bargaining in the shadow of the law. ${ }^{21}$ Legislators representing black voters thus held what Pamela Karlan has termed an important "bargaining chip" when they came to the table: the threat of a lawsuit under the VRA. ${ }^{22}$ If these experts are right, a failure to renew section 5 would be a disaster for racial minorities because it would take away the bargaining chip that has made political success possible. ${ }^{23}$

The problem with this debate is that it is all but impossible to resolve. We cannot determine whether we have, indeed, reached the stage of "normal politics" because of what I have elsewhere termed the "endogeneity problem." 24 It is extraordinarily difficult to tell whether successful bargaining by minority legislators is due to their increased legislative power (a sign we have reached "normal politics") or to the fact that they can credibly threaten to bring a VRA lawsuit. There is, in short, no way to be sure what a world without the VRA would look like. The experts thus seem to be mired in an endless debate, with neither side able to prove that its empirical hunch is correct.

centered on the use of competition to police second-order voting rights issues rather than first-order questions like ballot access. Abigail Thernstrom, however, has repeatedly argued that section 5 should expire. See, e.g., Abigail Thernstrom \& Edward Blum, OpEd., Do the Right Thing, Wall St. J., July 15, 2005, at A10; Abigail Thernstrom, Op-Ed., Emergency Exit, N.Y. Sun, July 29-31, 2005, at 10.

21. The phrase "bargaining in the shadow of the law" was first used by Robert Mnookin and Lewis Kornhauser. See Robert H. Mnookin \& Lewis Kornhauser, Bargaining in the Shadow of the Law: The Case of Divorce, 88 Yale L.J. 950 (1979).

22. Pamela S. Karlan, Georgia v. Ashcroft and the Retrogression of Retrogression, 3 Election L.J. 21, 36 (2004) [hereinafter Karlan, Retrogression] (noting that minority voters' gains "have all occurred in the shadow of Section 5" and arguing that it provides them "an invaluable bargaining chip"); see also Heather K. Gerken, Lost in the Political Thicket: The Court, Election Law, and the Doctrinal Interregnum, 153 U. Pa. L. Rev. 503, 533 (2004) [hereinafter Gerken, Political Thicket] (arguing that if bargaining power is lost, "we might worry whether the process is fair"). This claim is buttressed by Bruce Cain and Karin Mac Donald's empirical study of section 5, which suggests that "risk aversion drives much of the nearly universal compliance with the VRA." Bruce E. Cain \& Karin Mac Donald, Voting Rights Enforcement: Navigating Between High and Low Expectations 2 (June 24, 2005) (unpublished manuscript, on file with the Columbia Law Review).

23. Even if section 5 expires, localities will continue to bargain in the shadow of section 2 of the Voting Rights Act. In its present form, however, section 2 does not seem to cast a long enough shadow to serve the same role section 5 now plays. First, it requires a lawsuit to be filed, placing the burden of proof on the plaintiffs and demanding a significant investment of resources from them. Second, section 2 has been used almost exclusively in the area of districting and has not consistently been deployed as a tool for policing the type of nitty-gritty election procedures that section 5 regulates. Those procedures may be too small to justify the filing of a suit (it is not, after all, a coincidence that we see section 2 suits mostly in areas with very high stakes, like districting), and it would take a great deal of time to build up the necessary precedent to extend section 2's reach to other, more routine voting practices.

24. Gerken, Political Thicket, supra note 22, at 533. 


\section{The Solution: Opting In to the Voting Rights Act}

The solution to this dilemma is not to try to resolve this intractable disagreement, but to develop a regulatory strategy flexible enough to work in the territory between the two extremes depicted by the Act's supporters and critics. We need a "third way" approach to voting rights enforcement, one that can be adapted to what everyone acknowledges is a changing regulatory environment.

An opt-in strategy provides such a middle-ground approach. Were the Voting Rights Act administered as an opt-in system, it would create space for community and legislative leaders to negotiate the best deal possible for racial minorities but place a bargaining chip in their pockets-a chance to demand that the Act's traditional constraints apply should bargaining break down. Political deals struck by racial minorities would be enforced, but the VRA would hang like the sword of Damocles over every negotiation.

This strategy is concededly not "normal politics," for a strong version of the opt-in approach would excuse racial minorities from "the obligation to pull, haul, and trade." 25 But it should alleviate the fears of VRA critics by reducing the risk that a deal favored by racial minorities could be upset by a court or the DOJ applying a rigid understanding of the VRA's requirements. ${ }^{26}$ At the same time, it would also avoid the dangers associated with a full-scale regulatory retreat by providing a safety net for racial minorities who find themselves negotiating in a hostile political environment.

Put differently, the renewal debate presents a difficult question: How should we allocate the risks associated with making the wrong empirical judgment about the current state of racial politics in this country? ${ }^{27}$ Those who think section 5 should lapse place the risk of mistake squarely with minority voters. If we are not yet nearing the realm of normal politics, minority voters may lose the many gains made during the last two decades of voting rights enforcement. Those who believe that section 5 should be renewed in its current form, in contrast, insist that the risks of mistake must be shouldered by the states, perhaps subjecting the covered jurisdictions (and sometimes minority voters themselves) to needless and costly interference by the courts and the DOJ.

An opt-in approach takes the middle ground in this debate. It requires states and minority voters to share the risk of mistake, placing a formal obligation on racial minorities to participate in the enforcement process while still guaranteeing them the basic safety net section 5 cur-

25. Justice Souter coined this phrase in Johnson v. De Grandy, 512 U.S. 997, 1020 (1994).

26. Cf. Issacharoff \& Karlan, Groups, supra note 16, at 49-50 ("Much of contemporary equal protection law is now directed to ... defending the rough and tumble world of interest-driven politics from the rights-focused intervention of constitutional law.").

27. Thanks to Guy Charles for posing the question in this way. 
rently provides. In the process, it would generate a new set of benefits for minority voters and perhaps the public at large.

What would an opt-in approach look like in practice? It should create space for community representatives, public interest groups, and other parts of civil society to strike a deal while preserving a chance for them to opt in to VRA coverage under the appropriate circumstances. Rather than having the DOJ review every possible change made within covered jurisdictions, the goal would be to create a set of institutional incentives and decisionmaking proxies that would induce cooperation between localities and community leaders and focus enforcement resources on bad actors.

The opt-in approach would thus start with a sunshine provision. Rather than preclearing the thousands of electoral changes localities make each year with the DOJ, covered jurisdictions would merely provide notice of the changes in a form easily accessible to the public sixty or ninety days in advance of making the change. ${ }^{28}$ Civil rights groups would then have a chance to negotiate with local officials over any change they found objectionable.

The incentives for compliance would stem from the threat of the opt-in. If the bargaining process is fair, a court or the DOJ will let the decision stand. That means that even a change that the DOJ might have found to be retrogressive under the current regime will stand if it emerges from a fair bargaining process or is properly "blessed" by representatives of the minority community. The key difference from the current regime is thus that the fate of any challenge would turn primarily on the fairness of the process that produced the change, not on its substantive merits.

If negotiations break down, however, the sword of Damocles falls. Civil rights groups or local citizens would have the right to opt in to VRA enforcement by filing a formal civil rights complaint (one signed by a certain number of community group members to avoid the problem of the solitary crank). Such a complaint would be significantly less burdensome to file than a traditional voting rights lawsuit (a simple one-page

28. As with the current system, a change could not be made unless (1) a certain amount of time has passed since the disclosure, and (2) no civil rights complaint had been filed. Filing of a civil rights complaint would, in effect, "stay" the change until the DOJ had completed its investigation. This proposal thus differs from the proposal made by the Reagan administration during the debate on the 1982 amendments. The Reagan administration proposed a mandatory notice provision, but it placed the burden of proof to challenge a change with the DOJ and demanded that the Department establish its entitlement to injunctive relief for any change it wished to challenge. Drew S. Days III \& Lani Guinier, Enforcement of Section 5 of the Voting Rights Act, in Minority Vote Dilution 167, 173-74 (Chandler Davidson ed., 1984). Under that proposal, the burden of proof would have rested with the DOJ, and the standard for obtaining relief would have been the high standard courts use to grant injunctions. Id. at 174. Under an opt-in approach, as under the current statutory scheme, the locality bears the burden of proof, and the decision to preclear rests with the DOJ. 
sheet identifying the proposed change that is the subject of the complaint ought to suffice). After all, the point here is merely to trigger the DOJ's investigation process, and it would unduly tax these groups' resources if filing took a good deal more effort than conducting a phone call with the DOJ. Further, just as covered jurisdictions have the burden of proof in seeking preclearance, ${ }^{29}$ so too they would retain the burden of proof in showing that the change challenged by a voting rights complaint is nondiscriminatory.

Opting in would bring into play the full range of remedies currently available under the statute. For instance, if a districting process excluded racial minorities, the default remedy might look like the types of remedies imposed prior to Ashcroft under section 2 (which typically requires a number of majority-minority districts that is roughly proportional to the group's share of the population) ${ }^{30}$ or under section 5 (which typically requires a plan that the DOJ would deem nonretrogressive). Similarly, as under the current system, the DOJ could refuse to allow any change in polling place location or registration practice that the jurisdiction failed to prove was nondiscriminatory.

In the long run, incentives for compliance increase. Localities known for running fair complaint resolution processes would receive more deference from the Department of Justice if it is ever asked to intercede. And we would expect the DOJ to ramp up its scrutiny of any locality consistently found to violate the requirements of the Act.

Finally, those representing minority voters should have a chance to police the policer by challenging the DOJ's decisions to preclear a change in court. Under the current regime, preclearance grants cannot be appealed. ${ }^{31}$ As discussed in greater detail below, ${ }^{32}$ the Department of Justice has become increasingly politicized in recent years as it deals with difficult questions at the intersection of race and politics. It is thus time to take another lesson from the administrative law playbook and treat DOJ decisions as one would the decisions of any other federal agency by allowing third parties to challenge them in court.

\section{A. Would an Opt-In Approach Work?}

The most obvious question is whether an opt-in approach would work. Although in Part II.B this Essay explores why it would not only work but work better than the options currently on the table, it is worth noting that similar efforts at what Ian Ayres and John Braithwaite have

29. City of Pleasant Grove v. United States, 479 U.S. 462, 469 (1987).

30. See Heather K. Gerken, New Wine in Old Bottles: A Comment on Richard Hasen's and Richard Briffault's Essays on Bush v. Gore, 29 Fla. St. U. L. Rev. 407, 419 (2001) [hereinafter Gerken, New Wine] (describing this pre-Ashcroft practice).

31. See infra note 65 .

32. See infra text accompanying notes 128-133. 
termed "responsive regulation" 33 have succeeded in areas like environmental law, welfare regulation, employment law, and consumer safety. ${ }^{34}$ Although the details of this approach vary dramatically with context, responsive regulation involves a flexible regulatory strategy that is keyed "to how effectively industry is making private regulation work" and partially "delegate[s] government regulation of the marketplace to public interest groups, to unregulated competitors of the regulated firms, and even to the regulated firms themselves." 35 These real-world successes in such varied regulatory environments suggest the possibility that a new approach

33. Ian Ayres \& John Braithwaite, Responsive Regulation: Transcending the Deregulation Debate (1992). Although I focus on the seminal work of Ayres and Braithwaite, numerous academics have sought to respond to the criticisms of commandand-control regulation by proposing a variety of strategies that share some, but not all, of the features of the responsive-regulation paradigm (and, in some cases, provide a different array of strategies for combating the problems of top-down regulation). See, e.g., David A. Dana, The New “Contractarian” Paradigm in Environmental Regulation, 2000 U. Ill. L. Rev. 35 (2000); Michael C. Dorf \& Charles F. Sabel, A Constitution of Democratic Experimentalism, 98 Colum. L. Rev. 267 (1998); Cynthia Estlund, Rebuilding the Law of the Workplace in an Era of Self-Regulation, 105 Colum. L. Rev. 319 (2005); Jody Freeman, Collaborative Governance in the Administrative State, 45 UCLA L. Rev. 1 (1997) [hereinafter Freeman, Collaborative Governance]; Jody Freeman, The Private Role in Public Governance, 75 N.Y.U. L. Rev. 543 (2000) [hereinafter Freeman, Public Governance]; Robert W. Hamilton, Prospects for the Nongovernmental Development of Regulatory Standards, 32 Am. U. L. Rev. 455 (1983); Douglas C. Michael, Cooperative Implementation of Federal Regulations, 13 Yale J. on Reg. 535 (1996); Charles F. Sabel \& William H. Simon, Destabilization Rights: How Public Law Litigation Succeeds, 117 Harv. L. Rev. 1016 (2004); Richard B. Stewart, Reconstitutive Law, 46 Md. L. Rev. 86 (1986). For those considering how to adapt the responsive-regulation paradigm to the field of election law, Cynthia Estlund's work on the role private rights of action can play in promoting selfregulation and Jody Freeman's work on the role private actors play in public governance are particularly useful. See Estlund, supra, at 325 (suggesting that private rights of action may make it unnecessary to enlist "direct state enforcement"); Freeman, Public Governance, supra, at 588-91 (describing role of private activity in lawmaking). For an indepth effort to catalog and synthesize the vast literatures dealing with post-New Deal regulatory models, see Orly Lobel, The Renew Deal: The Fall of Regulation and the Rise of Governance in Contemporary Legal Thought, 89 Minn. L. Rev. 342, 343 (2004). For a skeptical view of the responsive-regulation paradigm and a critique of many of its basic arguments, see Mark Seidenfeld, Empowering Stakeholders: Limits on Collaboration as the Basis for Flexible Regulation, 41 Wm. \& Mary L. Rev. 411 (2000).

34. For discussions of these areas, see, e.g., Freeman, Collaborative Governance, supra note 33, at 41-49 (discussing negotiations over rules for "fugitive emissions"); id. at 49-55 (discussing limited success of negotiations over OSHA workplace safety rules for steel workers and high-elevation construction workers); id. at 55-65 (discussing EPA's Project XL, an extensive scheme allowing companies to negotiate for and trade emission permits); Freeman, Public Governance, supra note 33, at 594-625 (discussing private and public roles in Medicaid and Medicare); Lobel, supra note 33, at 345-46 (noting that responsive regulation is incorporated as part of "new paradigm" that is "instigating change in a wide spectrum of policy issues . . . ranging from employment and environmental protection; to welfare, family, health, and education laws"). But see Seidenfeld, supra note 33, at 413 (criticizing recent collaborative efforts, including Project XL, for not being "truly collaborative" and offering more skeptical view of these programs).

35. Ayres \& Braithwaite, supra note 33, at 4 (internal cross references omitted). 
to voting-rights enforcement-one modeled on an administrative law model rather than traditional civil rights paradigm-could succeed.

There are at least three key aspects of the responsive-regulation paradigm that are relevant to this project. The first is sunshine. ${ }^{36}$ If we move from top-down regulation to a process open to public participation, it is essential that all the parties involved have access to the information necessary to help make sensible regulatory choices and to compare the performance of covered jurisdictions across states.

The second salient thread of the responsive-regulation literature has to do with regulatory escalation: using a mix of carrots and sticks to tailor the level of government intervention to whether the regulated party functions as a good actor or bad actor within the system (and, of course, to create incentives for more good actors to emerge) ${ }^{37}$ Responsive regulation thus targets limited enforcement resources to police the worst offenders while encouraging other regulated actors to govern themselves in a manner consistent with the agency's goals. ${ }^{38}$

The third relevant component of the responsive-regulation paradigm is what Ayres and Braithwaite term tripartism. ${ }^{39}$ Rather than using government resources alone to police the system, a tripartite approach relies on third parties-citizen groups, public interest watchdogs, whistleblowers-to assist in the regulatory process. It thus rests on the hope that collaborative negotiation may produce better regulatory outcomes than top-down regulation. Tripartism allows public interest

36. See id. at 57-58 (emphasizing importance of giving "access to all the information that is available to the regulator" to enable third parties to enforce regulatory objectives); Lobel, supra note 33, at 399 (describing "both private disclosure rules and public sunshine laws" as "central example[s] of . . . dynamic policy tool[s]").

37. See, e.g., Ayres \& Braithwaite, supra note 33, at 1-53 (using game-theoretic model to argue that "regulators will be more able to speak softly when they carry big sticks" and are able to offer less regulation as incentive).

38. See id. at 50 (suggesting that virtue among regulated actors can be encouraged when agency reserves its "big gun" for nonvirtuous actors). As is made clear infra Part II.B.2, the opt-in approach does not offer the sort of detailed, formal escalation scheme that Ayres and Braithwaite describe as their "tit-for-tat" model. Id. at 19. In order to create the type of system of escalating penalties that those authors envision, we would have to do a good deal more tinkering with the existing regulatory scheme than this Essay proposes. If we work within the basic framework of the current VRA, escalation under an opt-in approach would largely involve increased scrutiny and monitoring; it would not involve the DOJ's ratcheting up penalties for violations of the Act. Interestingly, Ayres and another coauthor, Jennifer Gerarda Brown, have suggested that an opt-in approach might work even in contexts where carrots, not sticks, are the only incentives for compliance. See Ian Ayres \& Jennifer Gerarda Brown, Mark(et)ing Nondiscrimination: Privatizing ENDA with a Certification Mark 1 (2005) (unpublished manuscript, on file with the Columbia Law Review), available at http://islandia.law.yale.edu/ayers/AyresBrown_Mark_et_ing\%20Non discrimination.pdf (suggesting that companies might opt in to coverage under not-yetenacted "Employment Non-discrimination Act" by signing licensing agreement that would give them right to advertise their compliance with Act's requirements).

39. See generally Ayres \& Braithwaite, supra note 33, at 54-100 (describing tripartism as way of solving problems of capture and cooperation in regulatory encounters). 
groups to take part in regulation by granting them "access to all the information that is available to the regulator," "a seat at the negotiating table," and "the same standing to sue or prosecute under the regulatory statute as the regulator." 40 Such a strategy allows public interest groups not only to monitor the regulated entities, but to monitor the regulating agency itself.

Although the opt-in approach pulls several threads from the fabric of the responsive-regulation paradigm, it does not fully reproduce that complex model, ${ }^{41}$ but instead cobbles together a variety of regulatory strategies that seem best suited to work in the voting rights context. ${ }^{42}$ Opt-in thus involves the costs and benefits associated with hybridization. There is, of course, a danger that the successes of other models cannot be reproduced in the election law context without a good deal more mimicry than proposed here.

The strength of the opt-in proposal, however, may also be its modesty. It is a change in degree, but not in kind, for voting rights enforcement. It does not purport to turn the world of election law regulation upside down but instead adapts a variety of strategies used elsewhere to the unique regulatory environment of election law. ${ }^{43}$ In doing so, it

\section{Id. at $57-58$.}

41. The responsive-regulation model, for instance, deals with every stage of the agency process, from setting standards to policing compliance. Opt-in generally accepts the existing set of standards governing local officials' conduct and focuses largely on the enforcement stage of the process.

42. As Jody Freeman emphasizes, the success of private/public programs depends on "highly contextual, specific analyses of both the benefits and dangers of different administrative arrangements, together with a willingness to look for informal, nontraditional, and nongovernmental mechanisms for ensuring accountability," thus requiring one to cobble together a variety of options to ensure a well-functioning and accountable regulatory system. Freeman, Public Governance, supra note 33, at 64-73.

43. Consider, for instance, a few examples of the differences between the voting rights arena and the world described by Ayres and Braithwaite. On the one hand, it is harder to build an effective incentive scheme for regulated entities in election law than in other areas. The most obvious problem, of course, is that elected officials do not directly bear the costs of regulation in the same way that private firms do. Daryl J. Levinson, Making Government Pay: Markets, Politics, and the Allocation of Constitutional Costs, 67 U. Chi. L. Rev. 345, 345 (2000). Even if one assumes that elected officials are indeed motivated by the "shaming" mechanisms section 5 deploys, the agencies on which Ayres and Braithwaite focus have a wide array of regulatory tools, ranging from gentle prods (like minor fines) to something akin to the nuclear option (such as revoking a company's license). See Ayres \& Braithwaite, supra note 33, at 35. The Department of Justice, at present and in the politically realistic future, does not possess this range of options. Voting rights enforcement has only modest and rarely used policing options that involve fines or imprisonment. See 42 U.S.C. $\$ 1973$ (2000). It thus rests heavily on the injunctive model rather than the damages model. Even within the injunctive realm, the usual practice does not allow for anything that resembles the nuclear option in other regulatory fields. The type of strong incentives that may play a key role in other areas therefore cannot assist much here. Other aspects of the responsive-regulation or "collaborative governance" model are similarly hard to reproduce in voting rights regulation. For instance, administrative strategies to encourage self-regulation often depend on the disclosure of 
brings to the fore existing, if underappreciated, regulatory practices in the election law arena-the Department of Justice's reliance on minority groups in administering section 5, the use of the "totality of the circumstances" test by the DOJ and the courts, and the Act's bailout provision. And it plays up the procedural underpinnings of the Supreme Court's most recent construction of section 5 in Georgia $v$. Ashcroft. ${ }^{44}$ Opt-in thus offers an approach that fits easily within the existing regulatory paradigm and would not require extensive changes to section 5 to function effectively. ${ }^{45}$

For an opt-in approach to succeed in this context, it must also work politically. And it should. First, an opt-in strategy ought to appeal to members in a wide range of political camps, including those parties and interest groups most likely to play a key role in the renewal debates. Second, we are at an odd moment in voting rights enforcement, in part due to the changing composition of the Court and in part due to the Court's own waffling on issues that are at the core of voting rights enforcement. ${ }^{46}$ The looming uncertainty of future Supreme Court rulings casts a long shadow. The parties and interest groups involved in the renewal process are now working behind a veil of ignorance-it is hard to make the predictions that matter most to the renewal calculus (What constraints will the Act impose on districting? How will the Court view the constitutional-

objective facts or objectively measurable goals (e.g., the number of accidents in a workplace or the amount of pollution emitted by a factory). See, e.g., Freeman, Public Governance, supra note 33, at 650-53 (discussing elements of successful audited selfregulation). In the voting rights arena, it is more difficult to come up with uncontested measures of minority empowerment that could be used in a similarly productive way.

On the other hand, there may be more incentives for whistleblowing in the voting rights arena than in the environment contemplated by Ayres and Braithwaite. Their tripartite scheme relies heavily on public interest groups as the third leg of the regulatory stool. In voting rights enforcement, there may be a broader range of players who can play that monitoring role-not just groups dedicated to the cause of minority empowerment, like the NAACP or Mexican American Legal Defense and Education Fund (MALDEF), but political parties and politicians of all stripes who may help enforce voting rights provisions solely for purposes of political gain or partisan payback. As one former DOJ official put it, "it is an old saw at the Department that sometimes your best case can be made by white officials in the region." Telephone Interview with Michael J. Pitts, Former Official, Voting Section, Civil Rights Div., U.S. Dep't of Justice (Aug. 1, 2005) (transcript on file with the Columbia Law Review).

44. For an analysis of Ashcroft's procedural underpinnings, see Gerken, Political Thicket, supra note 22, at 531-34.

45. Because the goal of this Essay is to offer a proposal that fits easily within the regulatory space currently occupied by section 5 , it retains many vestiges of the prior regime that one might alter or eliminate if one were writing on a tabula rasa. It also does not address a number of issues crucial to the renewal debate, including the determination of which states and localities ought to be deemed "covered jurisdictions" going forward.

46. Georgia v. Ashcroft, for instance, has eviscerated the longstanding practice of using majority-minority districts as the sole tool for empowering minority voters, see supra text accompanying notes 7-12, and the Supreme Court's rulings on Congress's powers to enforce the Fourteenth and Fifteenth Amendments have hardly been a model of clarity, see infra text accompanying notes 115-120. 
ity of a renewed section 5?). There is, as a result, room for political compromise, and a third-way approach allows each group to hedge its bets.

Consider how members of the party that will control the renewal process - the Republicans-are likely thinking about renewal. At least one camp of the Republican Party ought to find much to praise in the opt-in approach. It takes a deregulatory approach to voting rights enforcement, focuses on bad actors rather than forcing all covered jurisdictions to preclear every change they make, and reduces the level of enforcement if race ceases to infect the political process. What about the Republicans who have engaged in a much crasser calculus-those who favor renewal simply because they want to continue pressuring states to create majority-minority districts? Those Republicans will be playing some fairly steep odds, as Georgia $v$. Ashcroft strongly suggests that if members of Congress cannot provide more flexibility in the districting arena, the Court will do it for them. The benefit of an opt-in approach? It gives Republicans a chance to persuade minority voters that majority-minority districts best serve their needs-and to have a deal struck on that basis stick rather than being second-guessed by the courts or the DOJ.

Democrats similarly should find that an opt-in approach provides a reasonable compromise. Those Democrats who-along with many civil rights groups-worry about preserving this important tool in the civil rights arsenal ought to appreciate the benefits offered by an opt-in approach. To be sure, opt-in abandons the command-and-control approach that has long been the hallmark of voting rights enforcement. But in its place opt-in offers a robust safety net for minority voters, one that ought to give civil rights groups and minority communities a greater voice in the districting process than they presently enjoy. A more targeted and dynamic regulatory strategy may also be a safer route for VRA supporters because, for the reasons outlined below, ${ }^{47}$ it is more likely to survive constitutional scrutiny than an effort to renew section 5 in its current form. As for Democrats solely worried about their own political fates, opt-in gives them-as it gives Republicans-a chance to persuade minority voters that majority-minority districts are no longer a sensible strategy and to have the deal stick if they succeed in doing so. It gives them, in short, room to bargain with minority members of their own party over their shared political future.

\section{B. Why Is Opt-In a Better Solution than Maintaining the Status Quo or Allowing Section 5 to Expire?}

Even if an opt-in approach would work, the question is whether it would do a better job than the options currently on the table: maintaining the current regulatory structure (perhaps with some minor tweaks) or allowing section 5 to expire. This subpart argues that there are at least four reasons to prefer the opt-in approach: (1) It privileges local knowl- 
edge and community participation in protecting the right to vote; (2) it offers the right set of incentives for everyone involved and thus deploys enforcement resources more effectively; (3) it shifts the focus of the VRA from substance to process, perhaps opening up the political arena to a new array of voices and ideas; and (4) it may relieve some of the constitutional concerns looming over the renewal process.

1. Community Input into Voting Rights Enforcement. - The first reason to value an opt-in approach is that local public interest and civil rights groups, not distant bureaucrats in Washington, would decide which changes are worth investigating. As noted above, under current law, covered jurisdictions - those states and localities whose voting practices were deemed particularly egregious by Congress ${ }^{48}$-must preclear every change they make to their voting system. Small decisions (like changing a polling place) and big ones (like a decennial redistricting plan) must be approved by the Department of Justice or a court before they can be put into place. The DOJ thus sorts through thousands of preclearance requests each year to figure out what changes violate section $5 .{ }^{49}$

Under an opt-in approach, in contrast, localities would simply disclose what changes they planned to make in a publicly accessible format available to any public interest groups willing to take part in the enforcement process. ${ }^{50}$ Informal negotiations between community leaders and the locality would replace the DOJ investigation as the first step in the process.

Much could be done to ensure that the public disclosure mandate serves the same efficacious role as the preclearance requirement and that public interest groups function as effective private regulators. Not only would covered jurisdictions be required to publicize changes in advance of making them (in sufficient detail for monitoring purposes), but the information would be provided in a form that allows such organizations to compare data across jurisdictions so that potentially discriminatory patterns or outlier practices could be reasonably identified. ${ }^{51}$ We would also look to the DOJ to disseminate information about how it now identifies changes that are likely to be discriminatory. The DOJ has generated various sorting mechanisms for identifying practices likely to be the most troubling, ${ }^{52}$ and it would be helpful to provide information about such

48. 42 U.S.C. $\$ \S 1973 b(b), 1973 c$.

49. See supra note 3 .

50. This requirement is certainly no more burdensome than the current requirement for section 5 filings and, indeed, comports with the practice of some covered jurisdictions that require public notice of at least some types of electoral changes. See, e.g., Ala. Code $\S 11-42-2$ (LexisNexis 1975) (mandating notice for annexation decisions); Ga. Code Ann. §36-36-57 (2000) (same); La. Rev. Stat. Ann. § 18:535 (2004) (requiring notice for changes in polling places).

51. The DOJ already posts such requests online, although in a form that makes them tricky to evaluate in full. See DOJ Notices of Section 5 Activity, supra note 3.

52. Although there is no formal "triage" system at the DOJ and "everything is looked at quite closely," Telephone Interview with Anonymous II, Senior Official, Voting Section, 
proxies to on-the-ground civil rights groups. Indeed, the DOJ might even sponsor training sessions on a state-by-state basis to aid civil rights groups in monitoring localities and provide a clearing house for those groups to share information on their failures and successes going forward. ${ }^{53}$

One might worry that civil rights groups lack the resources to play such an important role in enforcing the right to vote. But they are already doing the type of legwork needed for an opt-in approach to work. ${ }^{54}$ The Department of Justice receives so many preclearance requests that it can-

Civil Rights Div., U.S. Dep't of Justice (Aug. 15, 2005) (transcript on file with the Columbia Law Review), DOJ officials with whom I spoke described the various cuts that DOJ administrators make in sorting through preclearance requests. A number of preclearance requests generally get only a minimal or "quick" review: those made in places with a tiny minority population, those in places where racial minorities dominate politics, those regarding the routine scheduling of special elections (like bond elections), or those regarding practices that obviously help minority voters (increasing polling places or lengthening polling hours). See Telephone Interview with Anonymous I, Former Official, Voting Section, Civil Rights Div., U.S. Dep't of Justice (Aug. 2, 2005) (transcript on file with the Columbia Law Review); Telephone Interview with Michael J. Pitts, supra note 43; see also Telephone Interview with David Becker, Former Official, Voting Section, Civil Rights Div., U.S. Dep't of Justice (Aug. 4, 2005) (transcript on file with the Columbia Law Review) (explaining that if quick review turns up problem, full review is then conducted). Similarly, certain preclearance requests tend to get more rigorous review (one signal is that they are sent first to an attorney rather than an analyst)-e.g., districting plans, annexations, certain changes in the method of election, majority-vote requirements, atlarge districting, those changes that had generated controversy within the relevant community, requests from a locality that has in the past received a large number of requests for information (a step that often signals a planned objection), and objection letters. Those practices-which were usually staffed with extra lawyers, Telephone Interview with Anonymous II, supra-were termed "red flag[s]," Telephone Interview with Anonymous I, supra; Telephone Interview with David Becker, supra, and received what one former DOJ official termed "heightened scrutiny," Telephone Interview with Michael J. Pitts, supra note 43.

53. According to several former staffers, the Voting Section conducts a formal training session for its own analysts and attorneys. Run by a nonlawyer, it teaches new DOJ staffers the sorting strategies the DOJ has used to ensure it focuses its energies on the right set of preclearance requests. Telephone Interview with Anonymous III, Senior Official, U.S. Dep't of Justice (Aug. 16, 2005) (transcript on file with the Columbia Law Review); see also Telephone Interview with Anonymous I, supra note 52; Telephone Interview with Anonymous II, supra note 52. Staff attorneys agreed that it was possible to instruct people about what set of questions ought to be answered in evaluating various types of preclearance requests. Telephone Interview with Anonymous II, supra note 52. The DOJ has also engaged in significant public education campaigns, appearing before various groups to promote compliance with section 5. Posner, Post-1990, supra note 2, at 95; Telephone Interview with Anonymous III, supra. For an example of an accessible guide to preclearance published in the 1980s, see Barbara Y. Phillips, How to Use Section 5 of the Voting Rights Act (3d ed. 1983).

54. See, e.g., Guy-Uriel Charles \& Luis Fuentes-Rohwer, Reexamining Section 5 of the Voting Rights Act 10-14 (June 24, 2005) (unpublished manuscript, on file with the Columbia Law Review) (documenting numerous instances in which DOJ relied on views of community group members in refusing to preclear electoral change). Indeed, Charles and Fuentes-Rohwer argue that the DOJ's objection letters reveal that it has been a longstanding practice in the DOJ to "act[ ] as advocates interceding on behalf of citizens of color or as mediators between citizens of color and government officials." Id. at 10 . 
not possibly evaluate all of them without help. Its "investigation" thus usually involves an informal call by a DOJ staffer to a civil rights group or an elected minority official to see if there is a problem, ${ }^{55}$ effectively allowing community leaders to opt in to a more rigorous variant of section 5 enforcement. According to DOJ staffers, "standard contacts" in a community include local minority officials and the local chapters of the NAACP or the League of United Latin American Citizens (LULAC). ${ }^{56}$ When calls are made to such individuals, "most know exactly what the score is," as "they are used to hearing from the DOJ." 57

Far from burdening civil rights groups, the sunshine provisions of this proposal might even ease the burden already shouldered by these groups by providing them a readily accessible means for identifying violations and pooling information. And it would provide a more transparent process for public interest groups and minority officials taking part in enforcement, one that makes public the role that community leaders now play privately in the enforcement process.

The primary difference between the current system and an opt-in approach? Under the current approach, the DOJ must initiate the investigation. It makes the preliminary cut as to what matters and what does not, and it makes the first call to civil rights groups or local officials in order to begin the fact-gathering process. Under an opt-in approach, members of the relevant community decide for themselves what is worth investigating and what is not. The fact-gathering legwork-the crucial and most burdensome step in the process-remains in both instances with members of the local community. In essence, the phone calls travel in the opposite direction-from the community to Washington rather than vice versa. And the work necessary to file a complaint should take little more time than a conversation with a DOJ official. ${ }^{58}$

55. Telephone Interview with Anonymous I, supra note 52; Telephone Interview with David Becker, supra note 52; Telephone Interview with Michael J. Pitts, supra note 43. As one senior DOJ official put it, "We're in Washington; they're there." Telephone Interview with Anonymous III, supra note 53. For another recent analysis of DOJ practices confirming the continued salience of minority representatives to the DOJ's review process, see Donahue, supra note 2, at 1674-75.

56. Telephone Interview with Anonymous I, supra note 52; see also Telephone Interview with David Becker, supra note 52 (noting that DOJ has "whole slew of contacts" in "almost every covered county"); Telephone Interview with Anonymous II, supra note 52 (noting that experienced analysts have "over years built up files of minority leaders in communities”); cf. Telephone Interview with Michael J. Pitts, supra note 43 (noting there is no formal list of contacts; who is called depends on context).

57. Telephone Interview with Anonymous I, supra note 52; see also Telephone Interview with David Becker, supra note 52 (stating that contacts "usually" know answer to DOJ officials' questions when contacted and indicating that he has "never had any trouble finding out" necessary facts from local contacts).

58. It is, of course, crucial that the work required of civil rights groups be minimal so that the filing of a formal complaint does not drain the resources of these groups. The same holds true of the bargaining process. The risk associated with requiring civil rights groups to bargain with local officials before opting in is that the bargaining process might take up too many of these groups' precious resources. In such a scenario, civil rights 
Asking civil rights groups to sort the wheat from the chaff would privilege local knowledge and encourage community involvement in civil rights enforcement. To the extent that resources are being prioritized, that decision would take place at the local level. And local leaders, especially those who have benefited from the training and assistance of the DOJ, ought to be better at making the "intensely local appraisals" 59 of what constitutes discrimination than an administrative agency in Washington. Not only do such groups possess the type of on-the-ground knowledge about local motives and electoral consequences that DOJ officials cannot possibly hope to possess, but they have a better sense of what matters to blacks and Latinos in their community.

Further, asking community leaders to take part in the enforcement process may give members of these communities a greater sense of efficacy and ownership over the enforcement process. ${ }^{60}$ After all, one of the primary criticisms directed at traditional administrative models is that "the agency alone is responsible for protecting the public interest." 61 At least as a formal matter, the current regulatory scheme treats racial minorities as passive wards of the DOJ. That formal allocation is, of course, belied by the active role that community group members already play behind the scenes in helping the DOJ. But under an opt-in approach, the statutory scheme would formally acknowledge the important work civil rights groups and private citizens already carry out informally. And it would give them genuine decisionmaking authority over how to prioritize law enforcement resources, a power these groups do not currently possess.

An iterative process involving decisionmakers at different levels also seems likely to generate a better solution to the regulatory problem in

groups might well conclude that even if the opportunity to bargain gives them more power in the process, the game would still not be worth the candle. It seems unlikely that civil rights groups will have this concern over big ticket issues, like districting. These groups already invest considerable resources in the districting process through negotiations and litigation, and the opt-in proposal insures these groups have a seat at the table-something the current process cannot guarantee them. But the concern seems quite salient in the context of the small changes that are the bread and butter of the preclearance process. To avoid this problem, the courts and the DOJ should closely scrutinize any locality that drags its feet during negotiations. If small issues cannot be dispatched quickly through negotiations (onerous bargaining sessions, after all, are not in the interest of either civilrights groups or local government officials), that fact would signal the type of recalcitrance that would justify an opt-in by the civil-rights group and close monitoring by the DOJ.

59. City of Mobile v. Bolden, 446 U.S. 55, 95 (1980) (White, J., dissenting).

60. Cf. Freeman, Collaborative Governance, supra note 33, at 23-24 ("Giving stakeholders an opportunity to participate directly in the rule-making process grants them a degree of 'ownership' over a rule and increases their commitment to its successful implementation.”).

61. Id. at 13; see also Estlund, supra note 33, at 333 (noting that post-New Deal shifts in employment regulation "render[] employees the passive beneficiaries of the government's protection”). 
question. ${ }^{62}$ On-the-ground solutions negotiated by local stakeholders seem more likely to generate creative alternatives than top-down regulation. To be sure, DOJ officials engage in some informal negotiation with localities when a proposed change seems problematic. In the end, however, DOJ officials are confined to a "yes" or "no" decision on preclearance. Local community leaders, in contrast, have more room to maneuver. They know what matters to the community, where they can give a little, and what other possibilities lie open at the local level. ${ }^{63}$

Further, an opt-in approach gives civil rights groups two bites at the apple: a chance to change the minds of local officials as well as to persuade the DOJ to take their side. No longer confined to informal lobbying with the DOJ or a costly lawsuit under section 2 of the Voting Rights Act, civil rights groups would have a process-based mechanism (negotiations with local officials) and a shaming mechanism (the filing of a formal complaint, which draws attention to the locality's recalcitrance) to add to their arsenals.

Finally, civil rights groups not only retain the tools necessary to regulate-or at least bypass - the regulator, but add to their arsenal. Under both the current regime and the opt-in approach, private citizens can file a lawsuit under section 2 of the Voting Rights Act if the Department of Justice fails to intervene when it ought to do so. ${ }^{64}$ They should also be given a chance to police the policer by filing suit in federal court to challenge DOJ decisions to preclear a change. ${ }^{65}$

62. Consistent with the basic assumption behind the responsive-regulation paradigm-that regulation should be tailored to the identity of the actor-Drew Days argues that the DOJ itself had better results from negotiation with covered jurisdictions than from "coercive measures." Days, supra note 2, at 61.

63. This possibility animates much of the work on "collaborative governance" and "responsive regulation." See generally Freeman, Collaborative Governance, supra note 33. The success of this approach depends, of course, on the possibility that multiple solutions exist to realize the same policy goal. Michael, supra note 33, at 543-44. But see Stewart, supra note 33, at 91-92 (suggesting that flexible approach may be less appropriate where "fundamental and universal" rights are at stake, "such as the right not to be discriminated against by reason of race").

64. For an in-depth exploration of the role that private rights of action can play in encouraging self-regulation and regulatory compliance, see generally Estlund, supra note 33.

65. A central goal behind tripartism is to ensure there is someone to "guard[ ] the guardian[ ]," to borrow Ayres and Braithwaite's term, and reduce the chance of agency capture. Ayres \& Braithwaite, supra note 33, at 54-57. Consistent with the switch to an administrative law approach proposed in this paper, see infra Part III.A., Congress ought to give civil rights groups the right to appeal a DOJ determination that the bargaining process was fair. Under current law, when the DOJ preclears a change, that decision cannot be appealed in federal court. See Nathaniel Persily, Options and Strategies for Renewal of Section Five of the Voting Rights Act 14-15 (June 24, 2005) (unpublished manuscript, on file with the Columbia Law Review) (suggesting right to appeal preclearance decisions as beneficial VRA reform); Posting of Dan Tokaji, Inside Justice: The Georgia ID Preclearance, to Election Law @ Moritz, at http://moritzlaw.osu.edu/blogs/tokaji/2005/ 11/inside-justice-georgia-id-preclearance.html (Nov. 17, 2005) (on file with the Columbia 
2. Creating the Right Set of Incentives for Those Involved in Policing Voting Rights. - A second reason to favor an opt-in approach is that it provides the right kind of incentives for those involved in monitoring elections. Localities, of course, have every reason to work with civil rights groups to avoid the initiation of formal proceedings against them. ${ }^{66}$ If civil rights groups can provide an alternative, nondiscriminatory option that satisfies a locality's concerns, local officials acting in good faith have every reason to settle the dispute. Even those localities that are unsympathetic to minority concerns have some incentive to comply. Because a civil rights complaint accusing the locality of malfeasance has a different normative significance than the run-of-the-mill preclearance request that every covered jurisdiction files for each change it makes, it can serve as a useful shaming device.

Moreover, local officials' conduct would factor in to any subsequent review of the proposed change. After all, were a locality to act in bad faith by engaging in pro forma review or consistently ignoring sensible alternatives proposed by civil rights groups, that fact would presumably raise eyebrows within the DOJ should an opt-in occur. In such instances, one would expect the DOJ to escalate its enforcement strategy, either by invoking formal VRA remedies without extensive investigation or by putting in place a more intensive monitoring system. ${ }^{67}$

Concomitantly, localities known for running fair complaint resolution processes would likely receive more deference from the DOJ when it investigates a complaint. Indeed, one could even imagine the DOJ creating something akin to the safe harbor the Supreme Court has offered to employers with sound sexual harassment policies. ${ }^{68}$ This type of defer-

Law Review) (arguing that Congress should consider means to check DOJ's "power to preclear, which right now is effectively unreviewable").

66. Indeed, even under the current scheme, the mere request for additional information-a discovery request that precedes the decision to file an objectionsometimes leads a locality to "fold." Telephone Interview with Anonymous I, supra note 52.

67. There is some evidence that the DOJ already adheres to this practice informally. First, in a few instances it gives a closer look to potentially troubling requests coming from localities against whom a large number of information requests or objections were made. See Telephone Interview with Anonymous I, supra note 52; Telephone Interview with Anonymous II, supra note 52 (noting that while practice was not formally required, it comports with "common sense"); Telephone Interview with Michael J. Pitts, supra note 43 (noting that "history of problems that are well-known in the section" can result in "heightened scrutiny"). But see Telephone Interview with Anonymous III, supra note 53 (stating that "places do change," so large number of prior objections does not predestine locality for higher scrutiny). Second, if a locality fails to provide all the information necessary for the DOJ's investigation, the DOJ "can object on that basis alone," although the practice is rare. Telephone Interview with Anonymous I, supra note 52.

68. See, e.g., Faragher v. City of Boca Raton, 524 U.S. 775, 805-08 (1998) (explaining that affirmative defense which "give $[\mathrm{s}]$ credit . . . to employers who make reasonable efforts to discharge their duty" to prevent sexual harassment is consistent with policy behind Title VII); Burlington Indus. v. Ellerth, 524 U.S. 742, 765 (1998) (describing affirmative defense from vicarious liability for employer who exercised "reasonable care" to stop sexual 
ence would create an incentive for local officials to set up sensible review procedures and work with community groups in setting election policies. It would serve as the rough, procedural equivalent to the Act's existing bailout provision. ${ }^{69}$

In the long run, this sort of iterated strategy may even create incentives for cooperation between localities and public interest groups. It may thus help shift the relationship between the two parties from a purely adversarial one-with each group seeking a win from the courts or the Department of Justice-to a relationship that places greater emphasis on what Jody Freeman terms "problem-solving."70

Civil rights groups and concerned local citizens will also be guided by the right incentives under an opt-in approach. One might worry that such groups would challenge every change localities propose, thus needlessly duplicating the preclearance process at the local level while failing to conserve the DOJ's resources. ${ }^{71}$ Or one might worry that civil rights groups will take unreasonable positions so that a strategy forcing localities to negotiate with such groups will serve no useful end.

Both concerns are misplaced. To begin, civil rights groups will want to present local officials and the DOJ with needles, not haystacks. After all, the groups' ability to effect change depends on a productive relationship with both. Flooding localities or the DOJ with weak claims means that the groups' complaints are likely to be ignored in the future. Similarly, if a group offers a cogent argument for every complaint it files, local officials and the DOJ are likely to pay more attention to its concerns going forward. ${ }^{72}$ As to the problem of overzealous advocacy, a locality need only strike bargains with reasonable partners. After all, the DOJ is as ca-

harassment). For an analysis of how internal governance structures might be coordinated with external legal mandates to combat workplace discrimination, see Susan Sturm, Race, Gender, and the Law in the Twenty-First Century Workplace: Some Preliminary Observations, 1 U. Pa. J. Lab. \& Emp. L. 639 (1998).

69. Under the Act's bailout provision, a covered jurisdiction can be exempted from section 5 coverage if it is able to show, inter alia, that it has fully complied with the Voting Rights Act over a ten-year period. See 42 U.S.C. $§ 1973 b(a)(2000)$.

70. Freeman, Collaborative Governance, supra note 33, at 22. Given the differences between an opt-in approach and other models, one would not want to place undue emphasis on these sunny predictions, and we ought to expect the relationship between the parties to remain more adversarial in the election arena than in those contexts where the two are jointly tasked with a shared rulemaking assignment.

71. Ayres and Braithwaite call this action "the problem of the zealous [public interest group]," and describe reasons to think that a responsive regulatory approach might reduce this problem. Ayres \& Braithwaite, supra note 33, at 75-78. For a deeply skeptical view, see Seidenfeld, supra note 33, at 427-66, 484-500 (discussing problem of "overzealous" public interest group and finding all proposed solutions to this problem insufficient).

72. For additional analysis of the role that courts and the DOJ might play in avoiding the potential costs associated with interest group involvement, see infra text accompanying notes 109-112. 
pable of ignoring the claims of recalcitrant interest groups as it is of scrutinizing the proposals of recalcitrant local governments. ${ }^{73}$

An opt-in approach also lets the DOJ properly deploy its enforcement resources because the approach is flexible enough to adapt to the two main categories of problems covered by section 5: run-of-the-mill preclearance requests and highly contested preclearance issues. Section 5 applies to all voting changes, from the arcane to the central, from the unimportant to the deeply contested. The DOJ's workload thus falls roughly into two categories: run-of-the-mill preclearance issues (changes in the location of polling places, minor alterations to voting rules, etc.), and election-law decisions that are almost always hotly contested, with annexation and redistricting topping the list. ${ }^{74}$

The problem of designing a sensible policing strategy is that the two categories offer different types of regulatory dilemmas. Run-of-the-mill preclearance changes are less likely to have a profound impact on minority voters, but their reduced salience means that it is easier for covered jurisdictions to sneak discriminatory changes past regulators. The challenge here is figuring out how to design a coverage mechanism that ensures that the right subset of changes comes to the attention of the Department of Justice.

Highly contested issues, by contrast, generate the opposite problem. Such issues almost always generate controversy, and someone will always want to request judicial or DOJ scrutiny. ${ }^{75}$ The problem here is not making sure that someone tries to opt in, but deciding when to let those that do opt in get the benefit of traditional VRA remedies. Hotly contested issues thus move us quickly into the area where the concerns of the Act's critics are most salient. When should the relevant decisionmaker secondguess the results of the bargaining process and when should it defer to the choices made by the minority representatives involved?

An opt-in approach works in both domains. For run-of-the-mill requests, an opt-in approach ensures that the DOJ looks at the right set of changes. Rather than investigate thousands of requests, it can focus on

73. Thus, while local governments cannot formally "opt in" to traditional VRA scrutiny under this approach, the process-based analysis proposed here also affords localities protection from the unreasonable demands of the other side. As long as the locality maintains a fair and reasonable bargaining process, it is entitled to what amounts to a functional safe harbor protecting it from liability.

74. These categories obviously overlap in some instances, particularly when an election is hotly contested. Consider, for instance, the energy devoted to disputes over the long lines at polling places and the lack of standards in counting ballots during the 2004 election. See Richard L. Hasen, Beyond the Margin of Litigation: Reforming U.S. Electoral Administration to Avoid an Election Meltdown, 62 Wash. \& Lee L. Rev. 937, 939-41 (2005).

75. As Michael Pitts succinctly puts it, "when it comes to redistricting, both Democrats and Republicans appear quite willing to sue first and ask questions later." Michael J. Pitts, Let's Not Call the Whole Thing Off Just Yet: A Response to Samuel Issacharoff's Suggestion to Scuttle Section 5 of the Voting Rights Act, 84 Neb. L. Rev. 605, 615-16 (2005). 
problems that are both serious enough to concern community leaders and divisive enough to prevent local negotiations from working. An optin approach, in short, lets the DOJ focus on needles, not haystacks. ${ }^{76}$

For highly contested issues, where someone will always want to invoke traditional VRA remedies, an opt-in approach is also effective in its role as the sword of Damocles. Because the DOJ's job is not to secondguess the political deal struck but to decide whether the bargaining took place under fair conditions, an opt-in approach tells the DOJ when to act and when to stay its hand. Under this approach, the DOJ will not prevent racial minorities from judging what is in their own best interest or striking the same kind of bargains regularly reached by other minority groups. ${ }^{77}$ But if racial minorities are unable to bargain under fair terms-the moment when DOJ involvement is most needed-the opt-in approach allows the DOJ to step in.

3. Shifting the Battle from Substance to Process. - Third, there is much to be said for waging election-law wars on the turf of process rather than substance. Under an opt-in approach, the job of the DOJ and the courts is not to determine whether the political bargain struck was the right one, but to assess whether the conditions for bargaining were fair. The focus, then, is not on substantive outcomes, but process inputs. And there are a number of reasons to think that process inquiries will better serve racial minorities-and our democracy-in the long run.

a. Process Judgments Will Generate Proxies Useful to Racial Minorities. Although figuring out what makes for a "fair" districting process is obviously a difficult endeavor, it is also the area where we can see intriguing opportunities for ensuring that new voices-community groups, advocates for racial minorities, even citizens-are heard during the districting

76. For instance, imagine one is given two groups of preclearance requests to review. One pile contains a thousand requests, and the reviewer knows that about ten are likely to be grounds for denial; the other contains twenty requests, and the reviewer knows that they all fall into a "suspect" category of practices. It is clear which pile is likely to get a more perfunctory review. Indeed, one might suspect that there will be more false negativesoverlooked but valid claims-in the first pile simply because at every moment the reviewer knows that the specific request before him is statistically unlikely to be one of the ten valid claims. Similarly, a reviewer who knows that the second pile has been presorted to weed out less serious claims might be more likely to find violations in the pile of twenty. William Stuntz makes this point with regard to the Supreme Court's review of certiorari petitions. William J. Stuntz, Looking for Needles in Haystacks (Oct. 24, 2005) (unpublished manuscript, on file with the Columbia Law Review). Noting the reluctance of Supreme Court clerks to recommend that the Court grant certiorari, he suggests that the reason for this reluctance is the knowledge that the odds that one has found one of the rare needles in the certiorari petition haystack are quite slim. Id. He also hypothesizes that clerks are likely to pay more attention to-and recommend more grants for- "paid" certiorari petitions than in forma pauperis petitions not only because the quality of the former exceeds the latter, but because someone has thought the question presented was serious enough to invest resources in pursuing it. Id.

77. See Richard H. Pildes, Remarks at The Coming Fire: Conference on the 2007 Renewal of the Voting Rights Act (June 24, 2005) (asking why we should prevent racial minorities from striking same types of deals that other electoral minorities can make). 
process. That is because the only realistic way for courts or the DOJ to assess what processes are fair is to develop a set of heuristics for gauging whether the interests of racial minorities were fairly considered. And those proxies are likely to create a better set of incentives for political elites to engage with the communities most affected by their decisions than the current system supplies.

Take redistricting as an example: Whether courts are reviewing a process or a result-whether they are adjudicating the fairness of a districting process or the plan itself-they must develop a set of proxies for gauging what is fair. We have already seen what such proxies look like when courts police districting outcomes: the almost routine imposition of majority-minority districts upon localities, ${ }^{78}$ precisely the type of command-and-control regulation that the Act's critics have decried.

Were courts to develop a set of proxies in the process arena, political elites would finally have a reason to engage with the communities affected by the decisions they make. Why? Just think about how any decisionmaker would figure out whether a process was "fair." Most would come up with a proxy that has already been deployed by the Supreme Court and the DOJ: the support of legislators who represent racial minorities. In Ashcroft, for instance, it obviously mattered a great deal to the Court that there was relative unanimity among African American representatives about the wisdom of the plan. ${ }^{79}$ Similarly, post-Ashcroft, the Department of Justice has declined to preclear a plan on the basis of "lack of support for the proposed change from minority-preferred elected officials," 80 and it has always relied on local minority officials for help in identifying changes worthy of an objection. ${ }^{81}$

The consistent use of such a proxy might even encourage the development of cross-racial coalitions and buttress the negotiating power of minority officials. After all, if the success of a districting plan depended on those in power engaging with legislators from minority communities, it would create a significant incentive to tailor the plan to the needs of those communities.

There is even some anecdotal evidence pointing to this possibility. Consider what occurred during the post-2000 redistricting cycle in New Jersey and Georgia. One story, of course, is that African Americans and Latinos had gained so much power prior to 2000 that they were able to play a major role in the districting process. ${ }^{82}$ But one might tell a differ-

78. For an analysis of why courts have adopted such a bright-line approach, see Gerken, New Wine, supra note 30, at 417-21.

79. See Georgia v. Ashcroft, 539 U.S. 461, 471 (2003) (noting African American and overall vote totals in Georgia Senate and House of Representatives).

80. Objection Letter from R. Alexander Acosta, Assistant Att'y Gen., Civil Rights Div., U.S. Dep't of Justice, to C. Havird Jones, Jr., Senior Assistant Att'y Gen., S.C. Office of the Att'y Gen. (Feb. 26, 2004), at http://www.usdoj.gov/crt/voting/sec_5/pdfs/1_022604.pdf (on file with the Columbia Law Review).

81. See supra notes 54-57 and accompanying text.

82. See, e.g., Issacharoff, Own Success, supra note 13, at 1716 (telling such a story). 
ent-and, I think, more plausible-story about both states, one that involves a variant of the opt-in strategy I am describing. On this view, lawyers advising the Democrats surely were concerned that (1) the Republicans would challenge the plan in court, and (2) the Court's prior jurisprudence endorsing majority-minority districts would prevent them from switching to a coalition-district strategy. And those lawyers might well have concluded that the best way to avoid such an outcome-the best way, in effect, to opt out of the VRA's pre-2000 districting formulawould be to win the support of as many minority legislators as possible. Thus, the political power that minority legislators wielded by virtue of their votes was presumably buttressed by the incentives that the threat of Voting Rights Act litigation created. The apparent result? Impressive evidence of coalitions among whites, African Americans, and Latinos in both districting processes. ${ }^{83}$ The opt-in strategy I am describing, then, would simply make explicit the incentives that, in my view, probably existed during the last districting cycle for those lawyers who wanted to pursue the coalition-district strategy. ${ }^{84}$

Representatives of minority communities, however, will not always be the best proxies for fairness in the long run. ${ }^{85}$ For instance, there will be instances where minority legislators negotiate from a position of weakness and support a plan merely because they had no choice. In such a case, we might see that the costs of maintaining legislative control are not distributed evenly-for instance, a plan where districts that elected white Democrats were preserved and the only incumbents threatened were those elected in majority-minority districts. ${ }^{86}$ There will also be districting processes where we have reason to doubt the motives of the minority representatives themselves-for instance, when they support a plan that guarantees safe seats for all incumbents even though they might have drawn districts that increased the power of minority voters. Even the minority legislators in Ashcroft might have been suspect. Admittedly, selfinterested legislators usually favor safe districts, and the legislators in Ashcroft chose more competitive districts for themselves. ${ }^{87}$ But they might have done so for self-interested reasons: It is usually better to be part of

83. See, e.g., Sam Hirsch, Unpacking Page v. Bartels: A Fresh Redistricting Paradigm Emerges in New Jersey, 1 Election L.J. 7, 22-23 (2002) (claiming, as an attorney representing Democrats in New Jersey, that one of the crucial lessons to be drawn from that districting experience is importance of cross-racial coalitions).

84. I should emphasize that, although I represented the Democratic Party in districting litigation prior to becoming an academic and the firm where I worked continues to do so, I was not involved in anything that took place in either New Jersey or Georgia. The argument I offer here is merely an educated guess as to what the lawyers involved were thinking.

85. See Karlan, Retrogression, supra note 22, at 33-34. For an in-depth empirical analysis of why one type of black elected officials-black mayors-have trouble satisfying their black constituents once elected, see J. Phillip Thompson III, Double Trouble: Black Mayors, Black Communities, and the Call for a Deep Democracy (2005).

86. I am indebted to Pam Karlan for this example.

87. Pildes, Constitutionalization, supra note 13, at 96. 
the majority party than the minority coalition, and the lure of committee chairs and legislative control might have led those legislators to make a different choice than their constituents would have preferred.

If we worry that legislators who represent racial minorities-like all legislators-are self-interested, courts might also take a chapter from the corporations rule book. In corporate law, when directors engage in a self-interested transaction, courts grant that transaction extremely deferential review if it is approved by a majority of disinterested shareholders. ${ }^{88}$ Discerning who is "disinterested" in any political negotiation is, of course, a difficult task. But the Ashcroft majority certainly made such a judgment about civil rights icon John Lewis, explicitly deferring to his testimony in part because he "is not a member of the State Senate and thus has less at stake personally in the outcome of this litigation." 89

One could imagine courts taking a more systematic approach for identifying disinterested parties and speculate as to the positive effect such an approach might have on redistricting. For example, courts might rely on the views of community leaders, civil rights groups, or good-governance watchdogs, all of whom lack a direct stake in the outcome. ${ }^{90}$ Were courts and the DOJ to use the "blessings" of such groups as a proxy for gauging a plan's fairness, it would introduce a new set of voices into the districting process and create more channels for articulating the views of the affected community. Political elites would have every incentive to obtain these groups' approval, thus giving civil rights groups a new and potentially more powerful role in regulating the electoral process.

Proxies need not be confined to community groups, of course. For instance, courts and the DOJ might measure a districting process against an idealized, "best practices" measure. They might grant safe harbors, for

88. For a basic articulation of the rule, see, e.g., In re Wheelabrator Techs., Inc. S'holders Litig., 663 A.2d 1194, 1200 (Del. Ch. 1995).

89. Georgia v. Ashcroft, 539 U.S. 461, 489 (2003).

90. The DOJ routinely relies on members of these groups to assist in preclearance, supra notes 55-57, and it has sometimes rested objections at least in part on the failure of the locality to involve such groups in the decisionmaking process. See Motomura, supra note 2, at 241-43 (reviewing early DOJ practices indicating that preclearance objections were sometimes based on absence of minority participation in decisionmaking process). For a more recent example of this practice, see also Letter from Ralph F. Boyd, Jr., Assistant Att'y Gen., Civil Rights Div., U.S. Dep't of Justice, to C. Havird Jones, Jr., Senior Assistant Att'y Gen., S.C. Office of the Att'y Gen. (Sept. 3, 2002), at http:/www.usdoj.gov/ crt/voting/sec_5/ltr/1_090302.htm (on file with the Columbia Law Review) (filing objection letter to Union County, South Carolina, noting that proposed plan was developed without formal public hearings or opportunity for black members of community to voice their concerns). 
instance, to nonpartisan districting commissions, ${ }^{91}$ citizen assemblies, ${ }^{92}$ or processes that featured significant community involvement and support. ${ }^{93}$

Further, if the point of deploying a proxy is to discern who best represents the views of the citizens affected by the districting plan, political elites would have real incentives to show that their preferred plan enjoyed the direct support of black and Latino voters. One could imagine, for example, a districting process that featured the introduction of focus groups, public education campaigns, deliberative citizen juries, or other strategies for demonstrating widespread minority support. Districting, then, would no longer be the province of the elites, as politicians of every stripe would have to build community support for any plan adopted.

All this is not to say that substance will not play any role in making process judgments. It would be perfectly appropriate for courts or the DOJ to use the deals brokered in other jurisdictions as a baseline for assessing whether minority group members were playing on a level playing field in the case at hand. The point here would not be to find a universal answer as to what outcomes are fair, but to have a sense of what other racial minorities were able to negotiate for themselves in other contexts. A deal that fell well short of the baseline might signal a process failure during the negotiations in question. ${ }^{94}$ Substance, in short, would simply be one evidentiary factor in assessing whether the process was fair rather than vice versa.

91. See Samuel Issacharoff, Gerrymandering and Political Cartels, 116 Harv. L. Rev. 593, 646-48 (2002) [hereinafter, Issacharoff, Gerrymandering]. For a spirited response, see Nathan Persily, In Defense of Foxes Guarding Henhouses: The Case for Judicial Acquiescence to Incumbent-Protecting Gerrymanders, 116 Harv. L. Rev. 649 passim (2002).

92. Two Canadian provinces have begun to experiment with citizen assemblies in the electoral context, asking randomly selected citizens to deliberate as to which electoral system best served the needs of the province. The first such assembly took place in British Columbia last year. For information on the assembly, its proposal, and what took place during the subsequent referendum process, see B.C. Citizens' Assembly on Electoral Reform, Making Every Vote Count: The Case for Electoral Reform in British Columbia (Dec. 2004), at http://www.citizensassembly.bc.ca/resources/final_report.pdf (on file with the Columbia Law Review).

93. For an interesting example of a procedural solution designed to encourage agencies to rely on scientific studies that have been vetted by an appropriate peer review process, see Nicholas Bagley \& Richard L. Revesz, OMB and the Centralized Review of Regulation 51-54 (Oct. 24, 2005) (unpublished manuscript, on file with the Columbia Law Review) (describing implementation of Information Quality Act).

94. This type of baselining occurs in other areas of public law. As Charles Sabel and Bill Simon point out, courts often measure the performance of a school, prison, or public housing system not only against a standard chosen by the party but against "the performance of comparable institutions." Sabel \& Simon, supra note 33, at 1019. And under the current regime, the DOJ itself compares the plan being precleared against plans proposed but not accepted during the districting process in assessing whether retrogression has occurred. 28 C.F.R. $\$ 51.59$ (e) (2005). 
Switching the focus of the courts and the DOJ from substance to process, then, creates the right sorts of incentives for healthy politics. Fighting redistricting wars on this turf ensures that the battle will be about who speaks for the minority community, not which voting rights strategy to impose on that community. And it would provide a healthy reminder that the Voting Rights Act is designed to benefit citizens, not political elites.

Moreover, such an approach seems much more likely to channel the energy of political elites-who represent a permanent feature of our political system-into more productive channels. In order to pass their preferred plan, political parties would have to figure out how to connect debates about electoral structures to everyday politics and work to insert these important issues into public debate. Legislators' political fates would be dependent not just on the votes of their colleagues, but the views of groups and individuals outside of the usual districting process. Politicians seeking to get their plans through would consult not with expert witnesses but community groups to establish what is "best" for blacks and Latinos. At the very least, one would expect that the harder political elites try to establish their bona fides as genuine representatives of black and Latino citizens, the more likely it is that the final plan will actually incorporate the views of the citizens most affected by these choices. An opt-in approach would thus help bring new voices into the districting process.

b. Potential Objections. - There are two obvious objections to the reliance on process inputs rather than substantive outcomes as a means of gauging what is "fair" under the Voting Rights Act. The first centers on whether process-based inquiries are so nebulous that they will be subject to partisan manipulation. The second objection centers on how we would determine what constitutes an appropriate "default" when the DOJ or a court finds that the process was unfair. I address each in turn.

i. Are Process-Based Inquiries Better than Substantive Ones? - It is certainly true that process-based inquiries, at least as an initial matter, are hardly likely to generate the sort of rigid, easily administered standards we find elsewhere in election law-for instance, the outright ban on poll taxes or the mathematical equality among district populations mandated by the principle of one person, one vote. ${ }^{95}$ But most of the preclearance inquiries the DOJ and the courts now field under the current system do not involve such easily administered standards. ${ }^{96}$ For instance, in the wake of Ashcroft, I take it as a given that in the all-important area of districting we cannot return to the days of mechanically applied standards

95. John Hart Ely famously quipped about the rigid demands of one person, one vote that "administrability is [the doctrine's] long suit, and the more troublesome question is what else it has to recommend it." John Hart Ely, Democracy and Distrust: A Theory of Judicial Review 121 (1980).

96. One author finds that the DOJ was conducting nuanced, case-by-case reviews of preclearance requests even before Ashcroft. Donahue, supra note 2, at 1672-76. 
for evaluating vote dilution but are stuck with a totality-of-the-circumstances test that depends heavily upon on-the-ground political realities. DOJ officials whom I interviewed stated that context also matters for most of the other types of assessments the DOJ makes, ${ }^{97}$ a level of unanimity that suggests we should avoid conflating the fact that the DOJ lodges few objections with the claim that the evaluation process is something that could be conducted by a witless bureaucrat. Indeed, one former DOJ official suggests that there is more discretion exercised in deciding whether a polling place can be moved than in assessing a districting plan. ${ }^{98}$ As the DOJ's own regulations state (presumably in an effort to deter localities trying to find safe harbors), "mechanical" review is often impossible because most section 5 questions require "the appraisal of a complex set of facts that do not readily fit a precise formula."99

The question, then, is whether courts and the DOJ will be better at making mushy process-based judgments than they will be at rendering equally nebulous decisions about what mix of influence, coalition, and majority-minority districts constitute a "fair" districting plan or whether a change in the location of a polling place constitutes retrogression. And there is reason to think that the process-based route is the better one.

While procedural and substantive judgments are equally contestable, both courts and the DOJ are likely to be better at addressing questions of who represents a community than what is best for the community. As noted above, the DOJ has already developed a set of heuristics as to what type of community leaders and localities are worthy of its trust, ${ }^{100}$ and it has explicitly relied on the absence of minority involvement in the decisionmaking process as a factor in its preclearance decisions. ${ }^{101}$ As one former senior DOJ official explained, "one of the first things we want to find out" is what the minority community's "position on [an issue] is"something learned from both minority elected officials and community leaders-and added that there is "no doubt that this is a factor" in a preclearance decision. ${ }^{102}$

97. Telephone Interview with Anonymous I, supra note 52; Telephone Interview with Anonymous II, supra note 52; Telephone Interview with Anonymous III, supra note 53; Telephone Interview with David Becker, supra note 52; Telephone Interview with Michael J. Pitts, supra note 43 .

98. Telephone Interview with Michael J. Pitts, supra note 43 (observing that "at least in redistricting you know what you are looking for," whereas courts have provided relatively little guidance about other types of challenges); see also Telephone Interview with Anonymous I, supra note 52 (noting that while "vast majority" of section 5 requests were easily precleared, there are a number of "very hard calls" even outside of the redistricting context).

99. Revision of Procedures of the Administration of Section 5 of the Voting Rights Act of 1965, 52 Fed. Reg. 485, 486 (Jan. 6, 1987).

100. Supra notes 54-57 and accompanying text.

101. See 28 C.F.R. $\$ 51.57$ (c)-(d) (2005).

102. Telephone Interview with Anonymous II, supra note 52. 
Similarly, courts routinely make such judgments in cases involving standing challenges or class actions. Indeed, there is at least anecdotal evidence that judges are more comfortable with making judgments about process than about outcomes. Consider, for instance, how much of the opinion in Ashcroft was devoted to describing the level of support for the challenged plan among black legislators. ${ }^{103}$ It was plainly the terrain where the Court felt most comfortable; the Justices could tell themselves that they were not making a choice about what type of representation was "best" for racial minorities, ${ }^{104}$ but merely vindicating the views of the relevant community.

One might argue, as does Samuel Issacharoff, that once the Department of Justice is given standards, not rules, to administer, it can engage in partisan manipulation of those standards. At this point, Issacharoff wonders, is the game still worth the candle? ${ }^{105}$ Here again, though, a process-based approach seems less vulnerable to Issacharoff's challenge. That is because in the realm of process, the incentives for the major political parties do not point as consistently in a particular direction. Think about the question of districting. When the debate is about districting outcomes-majority-minority districts versus coalition districts versus influence districts-it is all too easy to figure out where each party's interests lie. We thus are likely to distrust the judgment of a Republican Department of Justice when it favors majority-minority districting over coalition districts, just as we would be suspicious if a Democratic DOJ imposed coalition districts on legislators who had chosen a majority-minority districting strategy.

Judicial and administrative positions on what proxies to use for gauging a "fair" process, in contrast, seem less likely to have a consistent valence. If the DOJ commits to the view that minority legislators must be trusted in one state, it presumably must do the same in others. If the Supreme Court finds that deliberative polling is a fair strategy for assessing citizen preferences in one case, it presumably must do so in another. If a community organization can get most of its members to show up at a meeting in one county, the same activities ought to be credited in another. Clear political incentives seem especially likely to be absent if the courts and the DOJ begin to consider evidence about the preferences of local citizens, whose views will be shaped and framed during the districting process itself and thus extraordinarily difficult to predict ex ante.

In arguing in favor of a process-based inquiry over an outcome-based one, however, I am not putting forward a naïve vision of process inquiries

103. See, e.g., Georgia v. Ashcroft, 539 U.S. 461, 484, 486 (2002).

104. For a brief analysis on the tendency of judges to claim they are agnostic on questions of democratic theory, see Gerken, New Wine, supra note 30, at 413-15.

105. Issacharoff, Own Success, supra note 13 (raising questions about the continued efficacy of section 5 for preclearance requests that do not involve simple, rote decisions by staffers). 
as "neutral" or free from any underlying substantive commitments. ${ }^{106}$ There is little reason to think that a judgment about whether a process is "fair" or whether some group is a "genuine" representative of an affected community is somehow more objective than a judgment about whether majority-minority districts are better than coalition districts. Both a process-based judgment and an assessment of substantive outcomes will be freighted with contestable normative assumptions.

It is equally true that the approach I am suggesting will not, at least in the short run, lead to less litigation. To the contrary, there will be instances where minority legislators and civil rights groups are deeply divided over what is best for the minority community, ${ }^{107}$ or where the community itself will be deeply divided. Further, we should not be naïve about the path politics is likely to take should an opt-in approach be adopted. The moment that elites learn that community support matters, they will presumably try to create "shell" organizations that claim community support but are little more than political shills. We should also expect political parties to try to capture existing community groups and to fake the appearance of a healthy decisionmaking process.

The claim I am making, then, is simply that when a fight is inevitable, we ought to think hard about what, precisely, we want to fight about. In my view, we ought to welcome battles over who genuinely represents minority communities. ${ }^{108}$ Rather than having scholars or politicians play the role of philosopher king, opining about what is "best" for the minority community, we should channel our political and litigation energies into discerning what members of the minority community actually think about the question.

106. A longstanding critique of process-based theories is, of course, that any determinate conception of process demands choices about one's underlying substantive commitments. For seminal critiques along these lines, see Ronald Dworkin, Freedom's Law 76-81 (1996); Terrance Sandalow, Racial Preferences in Higher Education: Political Responsibility and the Judicial Role, 42 U. Chi. L. Rev. 653, 654 (1975); Laurence H. Tribe, The Puzzling Persistence of Process-Based Constitutional Theories, 89 Yale L.J. 1063, 1064 (1980); Mark Tushnet, Darkness on the Edge of Town: The Contributions of John Hart Ely to Constitutional Theory, 89 Yale L.J. 1037, 1046-48 (1980). For a recent defense of Ely-who, it is often said, perfected the process-based approach-see Michael C. Dorf, The Coherentism of Democracy and Distrust, 114 Yale L.J. 1237, 1240 (2005) (accepting premise of Ely's critics but defending basic thrust of Ely's work).

107. For instance, we have already witnessed such divisions between minority legislators and civil rights groups over post-2000 redistricting in places like Georgia and California. For a brief discussion of other, related problems that predate these controversies, see Butler, supra note 2, at 243-47.

108. Ayres and Braithwaite make a similar point, arguing that it is essential that what they term public interest group "guardianship" be "contestable"-that is, that a public interest group lose its standing to speak on behalf of citizens as its base declines. Ayres \& Braithwaite, supra note 33, at 83. In describing the most basic model of tripartism, they also consider the formal designation of a single public interest group to represent citizens. Id. at 58. For a skeptical view of the possibility that interest groups might play such a role, see Seidenfeld, supra note 33, at 487-90. 
Average citizens, of course, do not spend years thinking long and hard about the trade-off between substantive and descriptive representation or where polling places ought to be located. But they do know whom they trust and what kind of representation they want. I would thus expect black and Latino citizens to do precisely what other citizens do in making hard choices about other issues-rely on proxies, deploy heuristics, and look for guidance from community leaders.

One might object that there is no reason to think that community groups are any more "representative" of minority voters than legislators, especially given that there is no formal mechanism for holding them accountable akin to an election. There are at least two types of responses to this concern. First, as a practical matter, these groups are already speaking for minority voters through the informal and nontransparent process that the DOJ currently employs. ${ }^{109}$ If one is worried about accountability and representativeness, that concern holds equally true for the present regime. Indeed, if anything, an opt-in approach helps increase accountability by making the negotiating process more transparent.

Second, and more importantly, if a group wants to claim authority to speak for the community, it must establish its standing to do so. We can fight about issues related to representation and accountability in court just as we battle over the substantive voting rights issues that presently preoccupy judges and litigators. The difference between these two battlefields is that the terrain of process should generate a better set of incentives going forward-an incentive for groups to mobilize a broad membership, to create governance structures that create transparent decisionmaking processes and assure the group's accountability to its members, and to demonstrate deep community support for the positions the group is taking.

Consider, for instance, what has taken place in the community economic development movement. ${ }^{110}$ Funding for community development corporations (CDCs) is generally tied to provisions "designed to make the organization accountable to its membership and through the membership to the larger community," thus providing some ex ante incentives for community mobilization. ${ }^{111}$ Ex post incentives for community mobilization are created by the competition among CDCs for resources, as their ability to win new funds "depends in substantial part on their past records," including the ability to muster significant community support for the programs they have initiated. ${ }^{112}$ In a roughly similar fashion, we would expect that litigation over who genuinely represents racial minori-

109. Supra text accompanying notes 54-57.

110. See William H. Simon, The Community Economic Development Movement 167-93 (2001) (describing grassroots mobilization processes).

111. Id. at 169 .

112. Id. at 178-82; see also Ayres \& Braithwaite, supra note 33, at 83 (discussing importance of transparency and contestability in choosing among public interest groups to take part in negotiations). 
ties will, in the long run, generate more accountability and representation for those communities than the current regime.

Indeed, just as a battle on process grounds creates incentives for legislators to engage with racial minorities, so too does it encourage coalitions within a given community. If community groups are divided as to what is best for racial minorities, they will find it difficult to speak authoritatively on the community's behalf. Community group leaders thus have every incentive to work out a consensus or compromise. Their power, after all, comes from standing together.

What happens if the community remains genuinely divided? Judges should straightforwardly acknowledge that fact and choose a default-by deferring to one type of decisionmaker, following past practice, or even flipping a coin. But there is no reason to think that the existence of genuine and legitimate division ought to pose more of a problem for an optin approach than the current regime, unless one places great value on the (false) appearance of unanimity. There is no question that, at some point, someone must choose a course. But the need for a decision does not require us to pretend that the choice we are making is the only one that could be made. These are deeply political and highly contestable decisions, and we can acknowledge that fact at the same time we make a choice. Indeed, it seems better to recognize the existence of political difference on these issues than to pretend that there is a "right" answerdiscernable only by expert witnesses and judges-for structuring our electoral system.

ii. Choosing a Default. - The other difficult question to address in designing an opt-in strategy is what ought to be the appropriate "default" to use if the process breaks down. Here again, take districting as an example. For simplicity's sake, I have suggested that we begin with the types of remedies imposed prior to Ashcroft under section 2 (which typically requires a number of majority-minority districts that is roughly proportional to the group's share of the population) or under section 5 (which typically requires a plan that the DOJ would deem nonretrogressive).$^{113}$ Even here, however, a more flexible regulatory strategy might help us exit the current morass we now face in choosing which districting strategy is the better one for purposes of choosing a default.

One of the main benefits of a process-based approach over time is that it provides a dynamic feedback mechanism that ought to supply a great deal of useful information about the preferences of minority voters and the types of plans generated by a healthy negotiating process. The departure from a command-and-control approach to districting will allow new coalitions to develop and new approaches to flourish. For instance, it would be useful to know how often-and under what circumstancesopt-ins occur and what kinds of plans are generated from processes

113. See supra note 30 and accompanying text. 
deemed "fair" by the courts. Such information can-and ought to-inform our judgments about the default rule going forward.

Thus, even if we start with the default rule proposed above, one could imagine the courts, the DOJ, or Congress occasionally revisiting the substantive constraints imposed by the Voting Rights Act in light of the series of deals reached "outside" of it. Such a benchmarking strategy ${ }^{114}$ would tell us a good deal about the needs and interests of racial minorities in the current political environment-including whether they vary by region or level of government, whether legislators' views differ systematically from their constituents, and what kind of strategy is deployed in a given political situation.

Indeed, it is precisely this sort of dynamism that makes an opt-in approach an attractive regulatory strategy in the current political environment, as we move from a system of entrenched racial divisions to the world of normal politics. In such circumstances, predictions are extremely difficult to make, and an adaptive regulatory strategy-one that acknowledges the possibility of moving forward while providing a safety net in case of retrenchment-seems like the most sensible option.

4. Passing Constitutional Muster. - A final reason to favor an opt-in approach is that it may aid those defending the Voting Rights Act against the inevitable constitutional challenge that will follow renewal of section 5. Since the Supreme Court issued its decision in City of Boerne v. Flores, ${ }^{115}$ there has been significant debate as to whether Congress has the power to extend the life of section 5 in its current form and what sort of evidentiary record would be necessary to support such an extension. ${ }^{116}$ Boerne

114. The notion of "benchmarking" has been well developed by the democratic experimentalists, who in turn borrowed the idea from the practice of private firms. See Dorf \& Sabel, supra note 33, at 286 ("The immediate instigation of our design for democracy is a series of innovations by private firms . . ..”). Democratic experimentalism empowers local governments to develop local solutions to shared national problems. Id. at 340. In exchange for such grants of autonomy, localities pool information about the successes and failures of their programs at the state or federal level. This type of benchmarking allows others to compare solutions and eventually develop a set of best practices based on the information gained from local experimentation. See Joshua Cohen \& Charles Sabel, Directly-Deliberative Polyarchy, 3 Eur. L.J. 313, 325, 331-32 (1997) (describing how benchmarking "capture[s] the benefits of all relevant, locally tailored solutions . . . without paying the price of uniformity"); id. at 287-88 (describing "system of collaboration" as "enabl[ing] the actors to learn from one another's successes and failures"). The articles by Dorf \& Sabel, supra note 33, and Cohen \& Sabel, supra, serve as the seminal accounts of the democratic experimentalist approach.

115. 521 U.S. 507 (1997).

116. For analyses of what would persuade the Supreme Court that a renewed section 5 represents a constitutional exercise of congressional power, see, e.g., Richard L. Hasen, Congressional Power to Renew the Preclearance Provisions of the Voting Rights Act After Tennessee v. Lane, 66 Ohio St. L.J. 177, 188, 204-06 (2005) [hereinafter Hasen, Congressional Power]; Pamela S. Karlan, Two Section Twos and Two Section Fives: Voting Rights and Remedies After Flores, 39 Wm. \& Mary L. Rev. 725 (1998); Ellen D. Katz, Federalism, Preclearance, and the Rehnquist Court, 46 Vill. L. Rev. 1179 (2001); Ellen D. Katz, Reinforcing Representation: Congressional Power to Enforce the Fourteenth and 
announced that the test for prophylactic congressional legislation enforcing constitutional rights was that the legislation be "congruen $[\mathrm{t}]$ and proportional[ ]" to the underlying constitutional harm Congress sought to remedy. ${ }^{117}$ Board of Trustees of the University of Alabama $v$. Garrett added to that requirement by suggesting that Congress must also have a sufficient evidentiary record to justify congressional regulation. ${ }^{118}$ How rigorously Garrett's mandate will be enforced is less than clear, as subsequent decisions have at least called the broadest readings of that requirement into question. ${ }^{119}$ Further, because section 5 involves both racial discrimination and protection of the right to vote, some have suggested that it may be subject to more lenient constitutional scrutiny than other statutory provisions that have fallen under Boerne's axe. ${ }^{120}$

Regardless of whether the Supreme Court is likely to be more generous in scrutinizing the provisions of the VRA than it has been in reviewing other acts of Congress, at minimum we would expect the Court to demand some effort from Congress to tailor section 5's burdensome requirements and to build in an appropriate sunset. ${ }^{121}$ After all, the Court's decisions in Shaw v. Reno, ${ }^{122}$ Johnson v. De Grandy, ${ }^{123}$ and Georgia

Fifteenth Amendments in the Rehnquist and Waite Courts, 101 Mich. L. Rev. 2341 (2003) [hereinafter Katz, Reinforcing Representation]; Michael J. Pitts, Georgia v. Ashcroft: It's the End of Section 5 as We Know It (and I Feel Fine), 32 Pepp. L. Rev. 265 (2005); Pitts, Remedy, supra note 2; Victor Andres Rodríguez, Section 5 of the Voting Rights Act of 1965 After Boerne: The Beginning of the End of Preclearance?, 91 Cal. L. Rev. 769 (2003); Paul Winke, Why the Preclearance and Bailout Provisions of the Voting Rights Act Are Still a Constitutionally Proportionate Remedy, 28 N.Y.U. Rev. L. \& Soc. Change 69 (2003). On the significance of Boerne and its progeny more generally, see generally Robert C. Post \& Reva B. Siegel, Equal Protection by Law: Federal Antidiscrimination Legislation After Morrison and Kimel, 110 Yale L.J. 441 (2000); Robert C. Post \& Reva B. Siegel, Legislative Constitutionalism and Section Five Power: Policentric Interpretation of the Family and Medical Leave Act, 112 Yale L.J. 1943 (2003).

117. Boerne, 521 U.S. at 520.

118. 531 U.S. 356, 373-74 (2000), vacated, 344 F.3d 1288 (11th Cir. 2003).

119. See Tennessee v. Lane, 541 U.S. 509, 533-34 (2004) (upholding regulation as applied to access to courts cases as congruent and proportional); Nev. Dep't of Human Res. v. Hibbs, 538 U.S. 721, 740 (2003) (upholding regulation as congruent and proportional).

120. See, e.g., Hasen, Congressional Power, supra note 116, at 180 (suggesting that legislation targeted at combating racial discrimination may be given broader latitude (citing Tennessee v. Lane, 541 U.S. at 561-62 (Scalia, J., dissenting))); Katz, Reinforcing Representation, supra note 116, at 2403 ("[T]he deference accorded Congress in the realm of race and the vote suggests deference of a broader sort to electoral regulation more generally.”); see also Tennessee v. Lane, 541 U.S. at 563-64 (Scalia, J., dissenting) ("Broad interpretation was particularly appropriate with regard to racial discrimination, since that was the principal evil against which the Equal Protection Clause was directed. . . . When congressional regulation has not been targeted at racial discrimination, we have given narrower scope to $\$ 5$.”).

121. See Boerne, 521 U.S. at 532-33 (noting approvingly that section 5 is "confined to those regions of the country where voting discrimination had been most flagrant" and includes sunset provision).

122. 509 U.S. 630 (1993), rev'd sub nom. Shaw v. Hunt, 517 U.S. 899 (1996).

123. 512 U.S. 997 (1994). 
v. Ashcroft ${ }^{124}$ have sounded a consistent set of themes: a concern that the VRA not dissolve into a system of racial spoils, a worry that voting rights protections will entrench rather than undermine racial divisions, and a search for the right strategy to bring us closer to the world of normal politics.

A more flexible, locally informed, and targeted enforcement strategy should help reassure the Court that the VRA continues to represent a valid exercise of Congress's enforcement powers. First, it offers a set of functional limits to supplement the Act's formal coverage limits. By abandoning the Act's current command-and-control approach, opt-in ensures that federal intrusion into local politics is limited not only to select jurisdictions, but to those instances where there is evidence that the playing field is still tilted against racial minorities. After all, where racial minorities wield enough power in the political process to effect change, the DOJ and the courts will stay their hands. Similarly, even where blacks and Latinos lack significant bargaining power, a covered jurisdiction acting in good faith has every reason to try to accommodate the group's concerns. And DOJ preclearance is requested only when the issue is one that members of the community deem worthy of their attention. Thus, the trigger for additional administrative or judicial scrutiny occurs only when an issue is both important to the local minority community and problematic enough for bargaining to break down.

Second, an opt-in approach contains a built-in sunset provision. After all, when we reach the stage of normal politics-when racial minorities can hold their own in every bargaining process-then any excuse for federal intervention evaporates. This functional sunset provision thus supplements the formal time limitations Congress has placed on section 5 during each renewal debate. Section 5's functional sunset provision, in some sense, resembles what is also functionally a sunset provision embedded in section 2. Under section 2 of the Voting Rights Act, vote dilution cannot be established unless voting is racially polarized. ${ }^{125}$ When people cease to vote along racial lines, section 2 will become a paper tiger. So, too, with an opt-in approach. When we reach the stage of normal politics, section 5 can no longer be invoked. This functional sunset provision ought to help reassure this Court, which has long been preoccupied with the danger that the Voting Rights Act might entrench rather than alleviate racial tensions, that Congress has fashioned an appropriate remedial scheme.

\section{Coda: A Third Way for Election Law Scholarship?}

This project may offer an opportunity to find a middle ground, not only in the world of policymaking, but in academic circles as well. Although a full analysis of this possibility is beyond the scope of this Essay,

124. 539 U.S. 461 (2003).

125. Thornburg v. Gingles, 478 U.S. 30, 46 (1986). 
this Part briefly describes the ways in which this project synthesizes several distinct strands of scholarship by (1) incorporating the insights of administrative law, and (2) weaving together the participatory and elite-centered strands of election law scholarship.

\section{A. The Need to Turn to Administrative Law Paradigms to Protect the Right to Vote}

First, election law scholarship has long been thought of as combining the scholarly insights of two fields: constitutional law and political science. ${ }^{126}$ This Essay reframes the renewal issue as a puzzle about regulatory strategies. It thus draws on a different line of scholarship-administrative law-in figuring out how best to achieve the Act's aims.

When we talk about voting, we have long spoken in the grand discourse of rights. That is unsurprising given the constitutional roots of the protections afforded to minority voters. Election law scholars have consistently used the language of constitutional rights as well, often inflecting it with a healthy dose of political science.

While scholars like Richard Pildes and Samuel Issacharoff have urged election law scholars to look to other disciplines, like corporate law, and adopt a "structural approach," 127 section 5 hews closely to the rights model. It assumes two kinds of governmental actors: (1) the Department of Justice serving the role of a public attorney general, whose duty it is to protect racial minorities; and (2) a court resolving that suit. Under this model, the DOJ plays the role of a knight in shining armor, vindicating the rights of minority voters either by denying potentially discriminatory preclearance requests or suing localities on behalf of minority voters. And the courts, interpreting the Voting Rights Act, engage in top-down regulation of localities.

Two kinds of problems have arisen from this model, both of which could have easily been predicted by a scholar of administrative law. First, the DOJ's armor is occasionally tarnished. Politics has always played some role in section 5 enforcement; the Voting Rights Act, after all, occupies the fraught territory where race and politics intersect.

There is, however, mounting evidence that the Voting Section of the Department of Justice has been excessively politicized under the current Administration, ${ }^{128}$ and serious questions have been raised about its ability

126. Richard L. Hasen, Election Law at Puberty: Optimism and Words of Caution, 32 Loy. L.A. L. Rev. 1095, 1095 (1999).

127. Issacharoff \& Pildes, supra note 15, at 643.

128. See, e.g., William R. Yeomans, An Uncivil Division, Legal Aff., Sept.-Oct. 2005, at 20, available at http://www.legalaffairs.org/issues/September-October-2005/argument_ yeomans_sepoct05.msp (on file with the Columbia Law Review); Mark Posner, Evidence of Political Manipulation at the Justice Department: How Tom DeLay's Redistricting Plan Avoided Voting Rights Act Disapproval, FindLaw, Dec. 6, 2005, at http://writ.news.findlaw. com/commentary/20051206_posner.html (on file with the Columbia Law Review) [hereinafter Posner, Political Manipulation]. Samuel Issacharoff has written the leading 
to protect minority voters. Recent leaks to the media reveal that President Bush's political appointees have taken the unusual step of overruling the consensus view of career attorneys in at least two cases where the GOP stood to benefit, preclearing Georgia's voter identification provisions and Tom DeLay's re-redistricting in Texas. ${ }^{129}$ Further, the Voting Section has been hemorrhaging staffers during the last few years. ${ }^{130}$ Lest one think that these attorneys and analysts are just fleeing a Republican administration, it is worth noting that many worked under the first President Bush as well as President Reagan. ${ }^{131}$ Finally, political appointees in the Voting Section have recently instituted an unusual policy forbidding career attorneys from making recommendations on high-profile preclearance requests. ${ }^{132}$ Like the decisions to overrule the consensus view of staff attorneys in the Georgia and Texas cases, this change represents an obvious break from agency practice ${ }^{133}$ and further evidence that the Voting Section may not be the knight in shining armor that Congress envisioned when it entrusted the DOJ with administration of section 5 .

Unfortunately, the rights model does not provide an easy solution to this problem. Preclearance grants, as noted above, ${ }^{134}$ are not subject to judicial review. Thus, in many cases, there is no mechanism for policing the policer under the current regime.

Second, as the bulk of this Essay has demonstrated, even when one harbors no doubts about the DOJ's willingness to play the knight's role, the rights model's heavy reliance on courts to protect minority voters has become an increasingly unwieldy strategy for making the fine-grained, contextual analyses now required of courts in this changing political environment. Here again, the rights model seems to fall short.

scholarly piece raising questions about the ability of the DOJ to make the kinds of judgments about race and politics that are now frequently put to it. See Issacharoff, Own Success, supra note 13 .

129. See Dan Eggen, Criticism of Voting Law Was Overruled, Wash. Post, Nov. 17, 2005, at A1; Dan Eggen, Justice Staff Saw Texas Districting as Illegal, Wash. Post, Dec. 2, 2005, at A1; Posner, Political Manipulation, supra note 128.

130. See Dan Eggen, Civil Rights Focus Shift Roils Staff at Justice, Wash. Post, Nov. 1, 2005, at A1 [hereinafter Eggen, Civil Rights Focus]; Dan Eggen, Politics Alleged in Voting Cases, Wash. Post., Jan. 23, 2006, at A1 (noting that one-third of section's lawyers had left over past nine months) [hereinafter Eggen, Politics Alleged]; Yeomans, supra note 128.

131. See Eggen, Civil Rights Focus, supra note 130 (noting that "[l] ongtime litigators" have complained about the political appointees' conduct); Eggen, Politics Alleged, supra note 130 (quoting high-level DOJ official as noting that "I was there in the Reagan years, and this is worse”); Posting of Steven J. Mulroy, smulroy@memphis.edu, to election-law@ majordomo.lls.edu (Dec. 2, 2005) (on file with the Columbia Law Review) (agreeing with prior posting that many of the staffers leaving the DOJ worked under the first President Bush).

132. See Dan Eggen, Staff Opinions Banned in Voting Rights Cases, Wash. Post, Dec. 10, 2005, at A3; Michelle Mittelstadt, Voting-Rights Friction Building Inside Justice, Dallas Morning News, Dec. 9, 2005, at A1.

133. Posner, Political Manipulation, supra note 128.

134. See supra note 65 and accompanying text. 
If the traditional tools of civil rights enforcement are getting rusty, the tools of administrative law are well suited for the task at hand. Indeed, administrative law-with its focus on how best to structure and supervise agencies-has long dealt with the kinds of problems now plaguing section 5 .

For example, administrative law would treat the DOJ not as a knight in shining armor, but simply as an agency charged with administering a statute. Agencies, as any administrative law scholar will tell you, need monitoring. They can be captured by outside interests, ignore congressional directives, and make decisions on the basis of politics rather than expertise. Consistent with the administrative model, this Essay proposes judicial review of preclearance grants to give civil rights groups an opportunity to police the policer, ${ }^{135}$ as is traditionally the case with most agency decisions. This modest proposal, of course, represents only a preliminary step in thinking about how best to monitor the DOJ's performance as an agency. ${ }^{136}$

Similarly, as described in great detail above, ${ }^{137}$ administrative law offers a broader, more flexible array of regulatory tools than the rights model. Here again, while this Essay takes an initial step toward adapting some of the insights of administrative law scholars to the unusual terrain of voting-rights enforcement, there is a great deal more work to be done on this project.

\section{B. Blending Participatory and Elite-Centered Conceptions of Democracy}

This Essay explores new scholarly terrain in a second respect; it blends two distinct strains of election law scholarship itself. As with political theory, there is a basic divide in election law scholarship between those who emphasize the participatory dimensions of voting ${ }^{138}$ and those who subscribe to a more elite-centered understanding of the electoral

135. See supra text accompanying notes 31-32.

136. For another such effort, see Mark. A. Posner, The Politicization of Justice Department Decisionmaking Under Section 5 of the Voting Rights Act: Is It a Problem and What Should Congress Do? 15-18 (Jan. 2006), at http://www.acslaw.org/files/Section \%205\%20decisionmaking\%201-30-06.pdf (on file with the Columbia Law Review); Daniel P. Tokaji, If It's Broke, Fix It: Improving Voting Rights Act Preclearance, 49 How. L.J. (forthcoming Spring 2006) (manuscript at 32-36, 42-48, on file with the Columbia Law Review) (citing evidence of partisan manipulation in section 5 enforcement and suggesting strategies for cabining DOJ discretion).

137. See supra Parts I-II.

138. Lani Guinier is the most prominent election law scholar who writes in this vein. See, e.g., Lani Guinier \& Gerald Torres, The Miner's Canary: Enlisting Race, Resisting Power, Transforming Democracy (2002). Guinier is the intellectual heir to participatory theorists dating back to Mill and Rousseau; her more recent fellow travelers include Carole Pateman and perhaps Judith Shklar. In some taxonomies, participatory theorists are lumped together with deliberative democrats, see, e.g., Richard A. Posner, Law, Pragmatism, and Democracy 130-57 (2003) [hereinafter Posner, Law], although the two theories of democracy are distinct. 
process. ${ }^{139}$ Those who care about participatory politics reject the notion that elites should control the election process, including districting. The heirs to Schumpeter and Dahl, in contrast, tend to pride themselves on their clear-eyed view of politics. They criticize participatory theorists for ignoring the importance of power and argue that it is inevitable that elites will play a central role in electoral politics.

It would be too easy to suggest that one camp focuses unduly on ends and the other on means-to argue that participatory theorists have chosen the right end but fail to appreciate what tools realistically can be used to achieve those ends, while rebuking competitive theorists for mistaking a means to an end (political competition) as an end in itself. The literature on both sides of this debate is richly inflected with empirical and normative assumptions from top to bottom, ${ }^{140}$ and untangling the empirical from the normative proves to be a difficult, if not elusive, task. There are also divisions within these two sides of the scholarly discourse. For instance, competitive democrats may differ as to whether competition is a necessary or sufficient precondition for healthy politics. Nor should we be surprised by the fact that the values associated with our democratic aims are multiple and conflicting and that neither set of theorists has captured the full story. ${ }^{141}$

The argument presented here self-consciously blends elements of both the participatory and competitive theories of democracy. The Essay is certainly inflected with a basic normative assumption: The deeply con-

139. The most prominent election law scholars who write in this vein are Samuel Issacharoff and Richard Pildes. See, e.g., Issacharoff, Gerrymandering, supra note 91 (offering competitive theory of democracy to justify regulating political gerrymanders); Richard H. Pildes, Competitive, Deliberative, and Rights-Oriented Democracy, 3 Election L.J. 685 (2004) (reviewing Posner, Law, supra note 138) (exploring the use of competitive theories of democracy in the judicial regulation of politics); Pildes, Constitutionalization, supra note 13 (offering a survey of the Supreme Court's election law jurisprudence and exploring the ways political competition affects crucial issues before the Court). Generalist Richard Posner has joined their ranks. See Posner, Law, supra note 138, at 135-78 (distinguishing between "Concept I" and "Concept II" theories). These scholars are the intellectual heirs to Schumpeter. See Joseph A. Schumpeter, Capitalism, Socialism, and Democracy (1943). Recent fellow travelers include a wide range of scholars, such as Robert Dahl, Anthony Downs, and numerous other public choice scholars.

140. For an in-depth analysis of the theory of competitive democracy and its normative underpinnings, see Yen-Tu Su, The Possibilities of Competitive Democracy (Oct. 24, 2005) (unpublished manuscript, on file with the Columbia Law Review) (reviewing Posner, Law, supra note 138, and Ian Shapiro, The State of Democratic Theory (2003)). For an analysis of the two primary goals that competition serves, see David Schleicher, "Politics as Markets" Reconsidered: Natural Monopolies, Competitive Democratic Philosophy, and Primary Ballot Access in American Elections (June 2005) (unpublished manuscript, on file with the Columbia Law Review).

141. See Guy-Uriel E. Charles, Constitutional Pluralism and Democratic Politics: Reflections on the Interpretive Approach of Baker v. Carr, 80 N.C. L. Rev. 1103, 1106 (2002) (arguing that "judicial review of democratic politics must be evaluated from a multidimensional continuum"); Richard H. Pildes, Why Rights Are Not Trumps: Social Meanings, Expressive Harms, and Constitutionalism, 27 J. Legal Stud. 725, 727-33 (1998). 
tested questions about representation that are embedded in electoral regulation ought to be decided not by elites, but by members of the relevant community. But it is also cognizant of the useful role that elites play in generating political energy-the way they can serve as "conversational entrepreneurs" within the polity. ${ }^{142}$ The opt-in approach thus deploys an institutional mechanism-the political incentives generated by the Voting Rights Act-to generate a conversation among average citizens about reform. The hope, then, is to harness the energy of everyday politics, including the skills and talents of political entrepreneurs, in the service of reform.

Like much of the scholarship subscribing to an elite-centered view of politics, this Essay rests on a hydraulic account of political power. ${ }^{143}$ It assumes that power is a driving force behind politics and that the energy devoted to obtaining power will always find an outlet, much as water will always find its own level. As Samuel Issacharoff and Pamela Karlan put it, the "First Law of Political Thermodynamics" is that "the desire for political power cannot be destroyed, but at most, channeled into different forms." ${ }^{44}$ Closing one conduit where political energy is directed will simply lead politicians to seek another.

This Essay does not, however, rest on the view that all outlets are created equal. It thus tries to redirect political energies into more normatively attractive paths-here, encouraging more grass roots involvement in the structuring of the democratic process. Rather than trying to imagine how to take elites out of the districting process, it focuses on how to ensure those elites play a more productive role in districting than they currently do.

Any effort to democratize the process by which we choose electoral structures, of course, runs into at least two types of counterarguments. The first is a bit of a debater's point: the problem of the infinite regress. Encouraging more community involvement in structuring our election system may seem like a step in the right direction, for there is something profoundly antidemocratic about having nominally elected representatives choosing their own constituents so that their reelection is all but a fait accompli before a single ballot is counted. ${ }^{145}$ But the actors deciding who genuinely "represents" the community are unelected administrative

142. Robert W. Bennett, Talking It Through: Puzzles of American Democracy 37-39, 114 (2003).

143. For a thorough exploration of this idea grounded in cutting-edge political science literature, see Michael S. Kang, The Hydraulics and Politics of Party Regulation, 91 Iowa L. Rev. 131 (2005). For an exploration of this notion in the campaign finance context, see Samuel Issacharoff \& Pamela S. Karlan, The Hydraulics of Campaign Finance Reform, 77 Tex. L. Rev. 1705 (1999) [hereinafter Issacharoff \& Karlan, Hydraulics].

144. Issacharoff \& Karlan, Hydraulics, supra note 143, at 1705.

145. For an exploration of this problem using the lens of democratic theory, see Dennis F. Thompson, Who Should Govern Who Governs? The Role of Citizens in Reforming the Electoral System (Oct. 1, 2005) (unpublished manuscript, on file with the Columbia Law Review). 
and judicial officials. Why shouldn't they, too, be democratically accountable?

The answer to this critique is necessarily a pragmatic one. At some point, the ground rules for democratic engagement must be laid down by someone. Any variant of democracy one might choose requires a lessthan-democratic act to begin it.

Thus, the real question is whether this solution presents the best available institutional structure for translating our democratic aims-in an admittedly imperfect fashion-into reality. At the very least, an opt-in approach represents an improvement on the current system. It replaces undemocratic choices-self-interested elites making the rules about how the game of politics is played-with a more democratic alternative in which community views are taken into account (albeit by unelected judges and administrators using democratic criteria to do so). And it introduces a new dynamic into the game of politics-a political "win" comes not merely from controlling legislative votes, but from proving that one is, indeed, entitled to the honorific "representative."

The second, more telling critique is that the opt-in approach replaces one type of paternalism with another, potentially more pernicious variant. One would assume that racial minorities, like all groups, hold a diverse range of views and cannot possibly be represented by a single voice. Why, then, should we try to identify "the" true representative of the group? At least, one might think, elections allow those choices to be made by the voters themselves.

Our current election system, of course, does not allow these choices to be made by voters themselves, as elites decide how voters are grouped. ${ }^{146}$ The question is whether one wants to gamble that an opt-in approach creates more room for community voices to be heard than the current regime. Opt-in invites us to make a bet on polyphony. It begins with the assumption that political elites have too much influence over districting decisions and tries to find the appropriate counterweight. The choice of an opt-in approach thus embodies the hope that competition among different types of representatives with different types of aims and interests will work better in representing the community than a narrow competition among legislative elites. Far from trying to identify the single, true representative of a community, it is premised on the assumption that communities can be represented in many different ways. But it also challenges those many stand-ins for voters to find some common ground.

\section{Conclusion}

As Congress holds hearings on the Voting Rights Act, it is likely to find that experts in the field are at loggerheads. They cannot agree about the facts on the ground, nor can they agree upon the next step Congress should take.

146. See, e.g., Guinier \& Torres, supra note 138, at 168-222. 
The solution is not to abandon the all-important project of voting rights enforcement nor to maintain the status quo, but to choose an approach that seeks a middle ground between the warring parties. We should adopt an adaptive regulatory strategy that creates space for us to move forward in this highly fraught area where race and politics intersect but provides a safety net in case of retrenchment. The opt-in approach is the right strategy for the situation in which we find ourselves-where stakes are high and good predictions are hard to come by. It creates the right sorts of incentives for everyone in the system-public interest groups, local governments, courts, and the Department of Justice. And it might even create new channels for genuine community involvement in structuring our democracy, something that is woefully absent from our current system. 